\title{
House Prices, Credit Growth, and Excess Volatility: Implications for Monetary and Macroprudential Policy
}

\author{
Paolo Gelain \\ Norges Bank \\ Kevin J. Lansing \\ Federal Reserve Bank of San Francisco and Norges Bank \\ Caterina Mendicino \\ Bank of Portugal
}

February 2013

Working Paper 2012-11

http://www.frbsf.org/publications/economics/papers/2012/wp12-11bk.pdf

The views in this paper are solely the responsibility of the authors and should not be interpreted as reflecting the views of the Federal Reserve Bank of San Francisco or the Board of Governors of the Federal Reserve System. 


\title{
House Prices, Credit Growth, and Excess Volatility: Implications for Monetary and Macroprudential Policy*
}

\author{
Paolo Gelain ${ }^{\dagger}$ \\ Norges Bank
}

\author{
Kevin J. Lansing ${ }^{\ddagger}$ \\ FRB San Francisco and Norges Bank
}

\author{
Caterina Mendicino ${ }^{\S}$ \\ Bank of Portugal
}

February 1, 2013

\begin{abstract}
Progress on the question of whether policymakers should respond directly to financial variables requires a realistic economic model that captures the links between asset prices, credit expansion, and real economic activity. Standard DSGE models with fully-rational expectations have difficulty producing large swings in house prices and household debt that resemble the patterns observed in many industrial countries over the past decade. We show that the introduction of simple moving-average forecast rules for a subset of agents can significantly magnify the volatility and persistence of house prices and household debt relative to otherwise similar model with fully-rational expectations. We evaluate various policy actions that might be used to dampen the resulting excess volatility, including a direct response to house price growth or credit growth in the central bank's interest rate rule, the imposition of a more restrictive loan-to-value ratio, and the use of a modified collateral constraint that takes into account the borrower's wage income. Of these, we find that a debt-to-income type constraint is the most effective tool for dampening overall excess volatility in the model economy. While an interest-rate response to house price growth or credit growth can stabilize some economic variables, it can significantly magnify the volatility of others, particularly inflation.
\end{abstract}

Keywords: Asset pricing, Excess volatility, Credit booms, Housing bubbles, Monetary policy, Macroprudential policy.

JEL Classification: D84, E32, E44, G12, O40.

\footnotetext{
${ }^{*}$ Forthcoming, International Journal of Central Banking. For helpful comments and suggestions, we would like to thank Kim Abildgren, Pierpaolo Benigno, Allesandro Notarpietro, Kjetil Olsen, Bruce Preston, Vincenzo Quadrini, Øistein Røisland, Federico Signoretti, Anders Vredin, seminar participants at the Bank of Canada, the Norges Bank Macro-Finance Forum, Sveriges Riksbank, Swiss National Bank, the 2012 Meeting of the International Finance and Banking Society, the 2012 Meeting of the Society for Computational Economics, the 2012 ESCB Day-Ahead Conference in Malaga, the 2012 Central Bank Modeling Workshop hosted by the National Bank of Poland, the 2012 Dynare Conference, the 2012 Fall Conference of the International Journal of Central Banking hosted by the Central Bank of Chile, the 2012 Central Bank of Turkey conference on "Reserve Requirements and Other Macroprudential Policies," the 2012 Second Conference of the ESCB Macroprudential Research Network hosted by the European Central Bank, and the 2013 UCLA/FRB-San Francisco Conference on Housing and the Macroeconomy.

${ }^{\dagger}$ Norges Bank, P.O. Box 1179, Sentrum, 0107 Oslo, email: paolo.gelain@norges-bank.no

${ }^{\ddagger}$ Corresponding author. Federal Reserve Bank of San Francisco, P.O. Box 7702, San Francisco, CA 941207702, email: kevin.j.lansing@sf.frb.org or kevin.lansing@norges-bank.no

${ }^{\S}$ Bank of Portugal, Department of Economic Studies, email: cmendicino@bportugal.pt
} 


\section{Introduction}

Household leverage in many industrial countries increased dramatically in the years prior to 2007. Countries with the largest increases in household debt relative to income tended to experience the fastest run-ups in house prices over the same period. The same countries tended to experience the most severe declines in consumption once house prices started falling (Glick and Lansing 2010, International Monetary Fund 2012). ${ }^{1}$ Within the United States, house prices during the boom years of the mid-2000s rose faster in areas where subprime and exotic mortgages were more prevalent (Tal 2006, Mian and Sufi 2009, Pavlov and Wachter 2011). In a given area, past house price appreciation had a significant positive influence on subsequent loan approval rates (Dell'Ariccia, et al. 2011, Goetzmann, et al. 2012). Areas which experienced the largest run-ups in household leverage tended to experience the most severe recessions as measured by the subsequent fall in durables consumption or the subsequent rise in the unemployment rate (Mian and Sufi 2010). Recession severity in a given area appears to reflect the degree to which prior growth in that area was driven by an unsustainable borrowing trend - one which came to an abrupt halt once house prices stopped rising (Mian and Sufi 2012). Overall, the data suggests the presence of a self-reinforcing feedback loop in which an influx of new homebuyers with access to easy mortgage credit helped fuel an excessive run-up in house prices. The run-up, in turn, encouraged lenders to ease credit further on the assumption that house prices would continue to rise.

Figure 1 illustrates the simultaneous boom in U.S. real house prices and per capita real household debt that occurred during the mid-2000s. During the boom years, per capita real GDP remained consistently above trend. A common feature of all bubbles which complicates the job of policymakers is the emergence of seemingly-plausible fundamental arguments that seek to justify the dramatic rise in asset prices. The U.S. housing boom was no different. During the boom years, many economists and policymakers argued that a bubble did not exist and that numerous fundamental factors, including the strength of the U.S. economy, were driving the run-up in prices. ${ }^{2}$ But in retrospect, many studies now attribute the run-up to a classic bubble driven by over-optimistic projections about future house price growth which,

\footnotetext{
${ }^{1}$ King (1994) identified a similar correlation between prior increases in household debt ratios and the severity of the early 1990s recession using data for ten major industrial countries from 1984 to 1992 . King also notes that U.S. consumer debt more than doubled during the $1920 \mathrm{~s}$ - a factor that likely contributed to the severity of the Great Depression in the early 1930s.

${ }^{2}$ See, for example, McCarthy and Peach (2004) and Himmelberg, et al. (2005). In an October 2004 speech, Fed Chairman Alan Greenspan (2004a) argued that there were "significant impediments to speculative trading" in the housing market that served as "an important restraint on the development of price bubbles." In a July 1, 2005 media interview, Ben Bernanke, then Chairman of the President's Council of Economic Advisers, asserted that fundamental factors such as strong growth in jobs and incomes, low mortgage rates, demographics, and restricted supply were supporting U.S. house prices. In the same interview, Bernanke stated his view that a substantial nationwide decline in house prices was "a pretty unlikely possibility." For additional details, see Jurgilas and Lansing (2013).
} 
in turn, led to a collapse in lending standards. ${ }^{3}$ Reminiscent of the U.S. stock market mania of the late-1990s, the mid-2000s housing market was characterized by an influx of unsophisticated buyers and record transaction volume. When the optimistic house price projections eventually failed to materialize, the bubble burst, setting off a chain of events that led to a financial and economic crisis. The "Great Recession," which started in December 2007 and ended in June 2009, was the most severe economic contraction since 1947, as measured by the peak-to-trough decline in real GDP

Much of the strength of the U.S. economy during the mid 2000s was linked to the housing boom itself. Consumers extracted equity from appreciating home values to pay for all kinds of goods and services while hundreds of thousands of jobs were created in residential construction, mortgage banking, and real estate. After peaking in 2006, real house prices have retraced to the downside while the level of real household debt has started to decline. Real GDP experienced a sharp drop during the Great Recession and remains about 5\% below trend. Other macroeconomic variables also suffered severe declines, including per capita real consumption and the employment-to-population ratio. ${ }^{4}$

Nearly four years after the end of the Great Recession, the unwinding of excess household leverage is still imposing a significant drag on consumer spending and bank lending in many countries, thus hindering the vigor of the global economic recovery. ${ }^{5}$ In the aftermath of the global financial crisis and the Great Recession, it is important to consider what lessons might be learned for the conduct of policy. Historical episodes of sustained rapid credit expansion together with booming stock or house prices have often signaled threats to financial and economic stability (Borio and Lowe 2002). Times of prosperity which are fueled by easy credit and rising debt are typically followed by lengthy periods of deleveraging and subdued growth in GDP and employment (Reinhart and Reinhart 2010). As noted originally by Persons (1930), "When the process of expanding credit ceases and we return to a normal basis of spending each year...there must ensue a painful period of readjustment." According to Borio and Lowe (2002) "If the economy is indeed robust and the boom is sustainable, actions by the authorities to restrain the boom are unlikely to derail it altogether. By contrast, failure to act could have much more damaging consequences, as the imbalances unravel." This raises the question of what "actions by the authorities" could be used to restrain the boom? Our aim in this paper is to explore the effects of various policy measures that might be used to lean against credit-fueled financial imbalances.

\footnotetext{
${ }^{3}$ For a comprehensive review of events, see the report of the U.S. Financial Crisis Inquiry Commission (2011). Recently, in a review of the Fed's forecasting record leading up to the crisis, Potter (2011) acknowledges a "misunderstanding of the housing boom... [which] downplayed the risk of a substantial fall in house prices" and a "lack of analysis of the rapid growth of new forms of mortgage finance."

${ }^{4}$ For details, see Lansing (2011).

${ }^{5}$ See, for example, Roxburgh, et al. (2012).
} 
Standard DSGE models with fully-rational expectations have difficulty producing large swings in house prices and household debt that resemble the patterns observed in many industrial countries over the past decade. Indeed, it is common for such models to include extremely large and persistent exogenous shocks to rational agents' preferences for housing in an effort to bridge the gap between the model and the data. ${ }^{6}$ Leaving aside questions about where these preference shocks actually come from and how agents' responses to them could become coordinated, if housing booms and busts were truly driven by preference shocks, then central banks would seem to have little reason to be concerned about them. Declines in the collateral value of an asset are often modeled as being driven by exogenous fundamental shocks to the "quality" of the asset, rather than the result of a burst asset price bubble. ${ }^{7}$ Taken literally, this type of model would imply that the decline in U.S. house prices since 2007 was caused by something akin to a nationwide infestation of wood termites. Kocherlakota (2009) remarks: "The sources of disturbances in macroeconomic models are (to my taste) patently unrealistic... I believe that [macroeconomists] are handicapping themselves by only looking at shocks to fundamentals like preferences and technology. Phenomena like credit market crunches or asset market bubbles rely on self-fulfilling beliefs about what others will do." These ideas motivate consideration of a model where agents' subjective forecasts serve as an endogenous source of volatility.

We use the term "excess volatility" to describe a situation where asset prices and macroeconomic variables move too much to be explained by a rational response to fundamentals. Numerous empirical studies starting with Shiller (1981) and LeRoy and Porter (1981) have shown that stock prices appear to exhibit excess volatility when compared to the discounted stream of ex post realized dividends. ${ }^{8}$ Similarly, Campbell, et al. (2009) find that movements in U.S. house price-rent ratios cannot be fully explained by movements in future rent growth.

We introduce excess volatility into an otherwise standard DSGE model by allowing a fraction of households to employ simple moving-average forecast rules, i.e., adaptive expectations. Following the asset pricing literature, excess volatility is measured relative to the fluctuations generated by the same model under fully-rational expectations. We show that the use of moving-average forecast rules by a subset of agents can significantly magnify the volatility and persistence of house prices and household debt. The moving-average forecast rule embeds

\footnotetext{
${ }^{6}$ Examples include Iacoviello (2005), Iacoviello and Neri (2010), Walentin and Sellin (2010), and Kannan, et al. (2012), among others.

${ }^{7}$ See, for example, Gertler et al. (2012) in which a financial crisis is triggered by an exogenous "disaster shock" that wipes out a fraction of the productive capital stock. Similarly, a model-based study by the International Monetary Fund (2009, p. 110) acknowledges that "Although asset booms can arise from expectations...without any change in fundamentals, we do not model bubbles or irrational exuberence." Gilchrist and Leahy (2002) examine the response of monetary policy to asset prices in a rational expectations model with exogenous "net worth shocks."

${ }^{8}$ Lansing and LeRoy (2012) provide a recent update on this literature.
} 
a unit root assumption which tends to be partially self-fulfilling. As shown originally by Muth (1960), a moving-average forecast rule with exponentially-declining weights on past data will coincide with rational expectations when the forecast variable evolves as a random walk with permanent and temporary shocks. But even if this is not the case, a moving-average forecast rule can be viewed as boundedly-rational because it economizes on the costs of collecting and processing information. As noted by Nerlove (1983, p. 1255): "Purposeful economic agents have incentives to eliminate errors up to a point justified by the costs of obtaining the information necessary to do so... The most readily available and least costly information about the future value of a variable is its past value."

The basic structure of the model is similar to Iacoviello (2005) with two types of households. Patient-lender households own the entire capital stock and operate monopolisticallycompetitive firms. Our setup roughly approximates the highly skewed distribution of U.S. financial wealth in which the top decile of households own about $80 \%$ of financial wealth. Impatient-borrower households derive income only from labor and face a borrowing constraint linked to the market value of their housing stock. Expectations are modeled as a weightedaverage of a fully-rational forecast rule and a moving-average forecast rule. We calibrate the parameters of the hybrid expectations model to generate an empirically plausible degree of volatility in the simulated house price, household debt, and real output series. Our calibration implies that $30 \%$ of households employ a moving-average forecast rule while the remaining $70 \%$ are fully-rational. ${ }^{9}$ Due to the self-referential nature of the model's equilibrium conditions, the unit root assumption embedded in the moving-average forecast rule serves to magnify the volatility of endogenous variables in the model. Our setup captures the idea that much of the run-up in U.S. house prices and credit during the boom years was linked to the influx of an unsophisticated population of new homebuyers. ${ }^{10}$ Given their inexperience, these buyers would be more likely to employ simple forecast rules for future house prices, income, etc. One can also make the case that many U.S. lenders behaved similarly by approving loans that could only be repaid if house prices continued to trend upward indefinitely.

Survey data from both stock and real estate markets provides strong empirical support for considering extrapolative or moving-average type forecast rules. ${ }^{11}$ In a comprehensive study of the expectations of U.S. stock market investors using survey data from a variety of sources, Greenwood and Shleifer (2013) find that measures of investor expectations about future stock returns are positively correlated with past stock returns and investor inflows into mutual

\footnotetext{
${ }^{9}$ Using U.S. data over the period 1981 to 2006 , Levin et al. (2012) estimate that around 65 to $80 \%$ of agents employ moving-average forecast rules in the context of DSGE model which omits house prices and household debt.

${ }^{10}$ See Mian and Sufi (2009) and Chapter 6 of the report of the U.S. Financial Crisis Inquiry Commission (2011), titled "Credit Expansion."

${ }^{11}$ For a summary of the evidence, see Jurgilas and Lansing (2013).
} 
funds. They conclude (p. 30) that "[O] ur evidence rules out rational expectations models in which changes in market valuations are driven by the required returns of a representative investor...Future models of stock market fluctuations should embrace the large fraction of investors whose expectations are extrapolative." We apply their advice in the present paper to a model of house price fluctuations.

Case, et al. (2012) perform an analysis of survey data on people's house price expectations in four cities over the period 2003 to 2012 . They report (p. 17) that "12-month expectations [of house price changes] are fairly well described as attenuated versions of lagged actual 12-month price changes." Figure 2 shows that house price forecasts derived from the futures market for the Case-Shiller house price index (which are only available from 2006 onwards) typically exhibit a sustained series of one-sided forecast errors. The futures market tends to overpredict future house prices when prices are falling - a pattern that is consistent with a moving-average forecast rule. Similarly, the top panel of Figure 3 shows that U.S. inflation expectations derived from the Survey of Professional Forecasters tend to systematically underpredict subsequent actual inflation in the sample period prior to 1979 when inflation was rising and systematically overpredict actual inflation thereafter when inflation was falling. Rational expectations would not give rise to such a sustained sequence of one-sided forecast errors. ${ }^{12}$ The bottom panel of Figure 3 shows that the survey pattern of professional forecasters is well-captured by an exponentially-weighted moving-average of past inflation rates, where the weight $\lambda$ on the most recent inflation observation is 0.35 . Interestingly, a weight of 0.35 on the most recent inflation observation is consistent with a Kalman filter forecast in which the forecasters' perceived law of motion for inflation is a random walk plus noise (Lansing 2009).

The volatilities of house prices and household debt in the hybrid expectations model are around 1.5 times larger than those in the rational expectations model. Both variables exhibit significantly higher persistence under hybrid expectations. Stock price volatility is magnified by a factor of about 1.4, whereas the volatilities of output, inflation, consumption, and labor hours are magnified by factors ranging from about 1.2 to 1.4. These results are striking given that only $30 \%$ of households in the model employ moving-average forecast rules. The use of such forecast rules by even a small subset of agents can have a large influence on model dynamics because the presence of these agents influences the nature of the fully-rational forecast rules employed by the remaining agents.

Given the presence of excess volatility, we evaluate various policy actions that might be used to dampen the observed fluctuations. With regard to monetary policy, we consider a

\footnotetext{
${ }^{12}$ Numerous studies document evidence of bias and inefficiency in survey forecasts of U.S. inflation. See, for example, Roberts (1997), Mehra (2002), Carroll (2003), and Mankiw, Reis, and Wolfers (2004). More recently, Coibion and Gorodnichencko (2012) find robust evidence against full-information rational expectations in survey forecasts for U.S. inflation and unemployment.
} 
direct response to either house price growth or credit growth in the central bank's interest rate rule. With regard to macroprudential policy, we consider the imposition of a more restrictive loan-to-value ratio (i.e., a tightening of lending standards) and the use of a modified collateral constraint that takes into account the borrower's wage income. Of these, we find that a debtto-income type constraint is the most effective tool for dampening overall excess volatility in the model economy. We find that while an interest-rate response to house price growth or credit growth can stabilize some economic variables, it can significantly magnify the volatility of others, particularly inflation.

Our results for an interest rate response to house price growth show some benefits under rational expectations (lower volatilities for household debt, stock prices, and consumption) but the benefits under hybrid expectations are more limited (lower volatility for household debt). Under both expectation regimes, inflation volatility is magnified with the effect being more severe under hybrid expectations. Such results are unsatisfactory from the standpoint of an inflation-targeting central bank that seeks to minimize a weighted-sum of squared deviations of inflation and output from target values. Indeed we show that the value of a typical central bank loss function rises monotonically as more weight in placed on house price growth in the interest rate rule.

The results for an interest rate response to credit growth also show some benefits under rational expectations. However, these benefits completely disappear under hybrid expectations. Moreover, the undesirable magnification of inflation volatility becomes much worse. The results for this experiment demonstrate that the effects of a particular monetary policy can be influenced by the nature of agents' expectations. ${ }^{13}$ We note that Christiano, et al. (2010) find that a strong interest-rate response to credit growth can improve the welfare of a representative household in a rational expectations model with news shocks. Kannan, et al. (2012) find that an interest rate response to credit growth can help reduce the value of a central bank loss function in a rational expectations model with large and persistent housing preference shocks. Both of these results could be sensitive to the assumption that all agents employ fully-rational expectations.

Turning to macroprudential policy, we find that a reduction in the loan-to-value ratio from 0.7 to 0.5 substantially reduces the volatility of household debt under both expectations regimes, but output volatility is magnified. The volatility effects on other variables are generally small. For policymakers, these mixed stabilization results must be weighed against the drawbacks of permanently restricting household access to borrowed money which helps impatient households smooth their consumption. A natural alternative to a permanent change in

\footnotetext{
${ }^{13}$ Orphanides and Williams (2009) make a related point. They find that an optimal control policy derived under the assumption of perfect knowledge about the structure of the economy can perform poorly when knowledge is imperfect.
} 
the loan-to-value ratio is to shift the ratio in a countercyclical manner without changing its steady-state value. A number of papers have identified stabilization benefits from the use of countercyclical loan-to-value rules in rational expectations models. ${ }^{14}$ Another macroprudential policy approach, examined by Bianchi and Mendoza (2010), is to employ a pro-cyclical tax on debt which leans against over-borrowing by rational private-sector agents.

Our second macroprudential policy experiment achieves a countercyclical loan-to-value ratio in a novel way by requiring lenders to place a substantial weight on the borrower's wage income in the borrowing constraint. As the weight on the borrower's wage income increases, the generalized borrowing constraint takes on more of the characteristics of a debt-toincome constraint. Intuitively, a debt-to-income constraint represents a more prudent lending criterion than a loan-to-value constraint because income, unlike asset value, is less subject to distortions from bubble-like movements in asset prices. Figure 4 shows that during the U.S. housing boom of the mid-2000s, loan-to-value measures did not signal any significant increase in household leverage because the value of housing assets rose together with household mortgage debt in a self-reinforcing feedback loop. Only after the collapse of house prices did the loan-to-value measures provide an indication of excessive household leverage. But by then, the over-accumulation of household debt had already occurred. ${ }^{15}$ By contrast, the ratio of household mortgage debt to disposable personal income started to rise rapidly about five years earlier, providing regulators with an early warning signal of a potentially dangerous buildup in household leverage. Unfortunately, the signal was not heeded.

We show that the generalized borrowing constraint serves as an "automatic stabilizer" by inducing an endogenously countercyclical loan-to-value ratio. In our view, it is much easier and more realistic for regulators to simply mandate a substantial emphasis on the borrowers' wage income in the lending decision rather than to expect regulators to frequently adjust the maximum loan-to-value ratio in a systematic way over the business cycle or the financial cycle. ${ }^{16}$ For the generalized borrowing constraint, we impose a weight of $75 \%$ on the borrower's wage income with the remaining $25 \%$ on the expected value of housing collateral. The multiplicative parameter in the borrowing constraint is adjusted to maintain the same steady-state loan-to-value ratio as in the baseline model. Under hybrid expectations, the generalized borrowing constraint reduces the volatility of house prices and household debt,

\footnotetext{
${ }^{14}$ See, for example, Kannan, et al. (2012), Angelini, et al. (2010), Christensen and Meh (2011), and Lambertini, Mendicino and Punzi (2011).

${ }^{15}$ In a February 2004 speech, Fed Chairman Alan Greenspan (2004b) remarked "Overall, the household sector seems to be in good shape, and much of the apparent increase in the household sector's debt ratios over the past decade reflects factors that do not suggest increasing household financial stress." Similarly, in an April 2004 speech, Fed Governor Donald Kohn (2004) stated "And, while [household] debt has been increasing, assets on household balance sheets have been rising even more rapidly."

${ }^{16}$ Drehmann et al. (2012) employ various methods for distinguishing the business cycle from the financial or credit cycle. They argue that the financial cycle is much longer than the traditional business cycle.
} 
while mildly reducing the volatility of other variables or leaving their volatility essentially unchanged. Importantly, the policy avoids the large undesirable magnification of inflation volatility that is observed in the two interest rate policy experiments.

Comparing across the various policy experiments, the generalized borrowing constraint appears to be the most effective tool for dampening overall excess volatility in the model economy. The value of a typical central bank loss function declines monotonically (albeit slightly) as more weight is placed on the borrower's wage income in the borrowing constraint. The beneficial stabilization results of this policy become more dramatic if the loss function is expanded to take into account the variance of household debt. The expanded loss function can be interpreted as reflecting a concern for financial stability. Specifically, the variance of household debt captures the idea that historical episodes of sustained rapid credit expansion have often led to crises and severe recessions. ${ }^{17}$

Recently, the Committee on International Economic and Policy Reform (2011) has called for central banks to go beyond their traditional emphasis on flexible inflation targeting and adopt an explicit goal of financial stability. Similarly, Bank of England Governor Mervyn King (2012) recently stated "It would be sensible to recognize that there may be circumstances in which it is justified to aim off the inflation target for a while in order to moderate the risk of financial crises. Monetary policy cannot just mop up after a crisis. Risks must be dealt with beforehand." More formally, Woodford (2012) argues for an expanded central bank loss function that reflects a concern for financial stability. In his model, this concern is linked to a variable that measures financial sector leverage.

\subsection{Related Literature}

An important unsettled question in economics is whether policymakers should take deliberate steps to prevent or deflate suspected asset price bubbles. ${ }^{18}$ History tells us that bubbles can be extraordinarily costly when accompanied by significant increases in borrowing. On this point, Irving Fisher (1930, p. 341) famously remarked, "[O]ver-investment and over-speculation are often important, but they would have far less serious results were they not conducted with borrowed money." The use of leverage magnifies the contractionary impact of a decline in asset prices. The typical residential housing transaction is financed almost entirely with borrowed money. It is therefore not surprising that: (1) housing-bust recessions tend to be longer and more severe than stock-bust recessions (International Monetary Fund 2009), and (2) the severity of housing-bust recessions is positively correlated with prior increases in household

\footnotetext{
${ }^{17}$ Akram and Eitrheim (2008) investigate different ways of representing a concern for financial stability in a reduced-form econometric model. Among other metrics, they consider the standard deviation of the debt-toincome ratio and the standard deviation of the debt service-to-income ratio.

${ }^{18}$ For an overview of the various arguments, see Lansing (2008).
} 
leverage (Glick and Lansing 2010, International Monetary Fund 2012).

Early contributions to the literature on monetary policy and asset prices (Bernanke and Gertler 2001, Cecchetti, al. 2002) employed models in which bubbles were wholly exogenous, i.e., bubbles randomly inflate and contract regardless of any central bank action. Consequently, these models cannot address the important questions of whether a central bank should take deliberate steps to prevent bubbles from forming or whether a central bank should try to deflate a bubble once it has formed. In an effort to address these shortcomings, Filardo (2008) develops a model where the central bank's interest rate policy can influence the transition probability of a stochastic bubble. He finds that the optimal interest rate policy includes a response to asset price growth.

Dupor (2005) considers the policy implications of non-fundamental asset price movements which are driven by exogenous "expectation shocks." He finds that optimal monetary policy should lean against non-fundamental asset price movements. Gilchrist and Saito (2008) find that an interest-rate response to asset price growth is helpful in stabilizing an economy with rational learning about unobserved shifts in the economy's stochastic growth trend. Airaudo, et al. (2013) find that an interest-rate response to stock prices can stabilize an economy against sunspot shocks in a rational expectations model with multiple equilibria. Our analysis differs from these papers in that we allow a subset agents to depart from fully-rational expectations. We find that the nature of agents' expectations can influence the stabilization benefits of an interest rate rule that responds to house price growth or credit growth.

An empirical study by Chow (1989) finds that an asset pricing model with adaptive expectations outperforms one with rational expectations in accounting for observed movements in U.S. stock prices and interest rates. Huh and Lansing (2000) show that a model with backwardlooking expectations is better able to capture the temporary rise in long-term nominal interest rates observed in U.S. data at the start of the Volcker disinflation in the early-1980s. Some recent research that incorporates moving-average forecast rules or adaptive expectations into otherwise standard models include Sargent (1999, Chapter 6), Evans and Ramey (2006), Lansing (2009), and Huang, et. al (2009), among others. Huang, et al. (2009) state that "adaptive expectations can be an important source of frictions that amplify and propagate technology shocks and seem promising for generating plausible labor market dynamics."

Constant-gain learning algorithms of the type described by Evans and Honkapoja (2001) are similar in many respects to adaptive expectations; both formulations assume that agents apply exponentially-declining weights to past data when constructing forecasts of future variables. $^{19}$ Orphanides and Williams (2005), Milani (2007), and Eusepi and Preston (2011) all find that adaptive learning models are more successful than rational expectations models in

\footnotetext{
${ }^{19}$ Along these lines, Sargent (1996, p. 543) remarks "[A]daptive expectations has made a comeback in other areas of theory, in the guise of non-Bayesian theories of learning."
} 
capturing several quantitative properties of U.S. macroeconomic data.

Adam, et al. (2012) show that the introduction of constant-gain learning can help account for recent cross-country patterns in house prices and current account dynamics. In contrast to our setup, however, their model assumes the presence of volatile and persistent exogenous shocks to the representative agent's preference for housing services - a feature that helps their model to fit the data. Granziera and Kozicki (2012) and Gelain and Lansing (2013) show that simple Lucas-type asset pricing models with either extrapolative or moving-average type expectations can help account for numerous quantitative and qualitative features of U.S. house price data.

\section{The Model}

The basic structure of the model is similar to Iacoviello (2005). The economy is populated by two types of households: patient (indexed by $j=1$ ) and impatient (indexed by $j=2$ ), of mass $1-n$ and $n$, respectively. Impatient households have a lower subjective discount factor $\left(\beta_{2}<\beta_{1}\right)$ which generates an incentive for them to borrow. Nominal price stickiness is assumed in the consumption goods sector. Monetary policy in the baseline model follows a simple Taylor-type interest rate rule.

\section{$2.1 \quad$ Households}

Households derive utility from a flow of consumption $c_{j, t}$ and services from housing $h_{j, t}$. They derive disutility from labor $L_{j, t}$. Each household maximizes

$$
\widehat{E}_{j, t} \sum_{t=0}^{\infty} \beta_{j}^{t}\left\{\log \left(c_{j, t}-b c_{j, t-1}\right)+\nu_{j, h} \log \left(h_{j, t}\right)-\nu_{j, L} \frac{L_{j, t}^{1+\varphi_{L}}}{1+\varphi_{L}}\right\}
$$

where the symbol $\widehat{E}_{j, t}$ represents the subjective expectation of household type $j$, conditional on information available time $t$, as explained more fully below. Under rational expectations, $\widehat{E}_{j, t}$ corresponds to the mathematical expectation operator $E_{t}$ evaluated using the objective distributions of the stochastic shocks, which are assumed known by the rational household. The parameter $b$ governs the importance of habit formation in utility, where $c_{j, t-1}$ is a reference level of consumption which the household takes into account when formulating its optimal consumption plan. The parameter $\nu_{j, h}$ governs the utility from housing services, $\nu_{j, L}$ governs the disutility of labor supply, and $\varphi_{L}$ governs the elasticity of labor supply. The total housing stock is fixed such that $(1-n) h_{1, t}+n h_{2, t}=1$ for all $t$.

Impatient Borrowers. Impatient-borrower households maximize utility subject to the budget constraint:

$$
c_{2, t}+q_{t}\left(h_{2, t}-h_{2, t-1}\right)+\frac{b_{2, t-1} R_{t-1}}{\pi_{t}}=b_{2, t}+w_{t} L_{2, t},
$$


where $R_{t-1}$ is the gross nominal interest rate at the end of period $t-1, \pi_{t} \equiv P_{t} / P_{t-1}$ is the gross inflation rate during period $t, w_{t}$ is the real wage, $q_{t}$ is the real price of housing, and $b_{2, t-1}$ is the borrower's real debt at the end of period $t-1$.

New borrowing during period $t$ is constrained in that impatient households may only borrow (principle and interest) up to a fraction $\gamma$ of the expected value of their housing stock in period $t+1$ :

$$
b_{2, t} \leq \frac{\gamma}{R_{t}}\left[\widehat{E}_{1, t} q_{t+1} \pi_{t+1}\right] h_{2, t},
$$

where $0 \leq \gamma \leq 1$ represents the loan-to-value ratio and $\widehat{E}_{1, t} q_{t+1} \pi_{t+1}$ represents the lender's subjective forecast of future variables that govern the collateral value and the real interest rate burden of the loan.

The impatient household's optimal choices are characterized by the following first-order conditions:

$$
\begin{gathered}
-U_{L_{2, t}}=U_{c_{2, t}} w_{t} \\
U_{c_{2, t}}-\mu_{t}=\beta_{2} R_{t} \widehat{E}_{2, t}\left[\frac{U_{c_{2, t+1}}}{\pi_{t+1}}\right], \\
U_{h_{2, t}}+\beta_{2} \widehat{E}_{2, t}\left[U_{c_{2, t+1}} q_{t+1}\right]+\mu_{t} \frac{\gamma}{R_{t}} \widehat{E}_{1, t}\left[q_{t+1} \pi_{t+1}\right]=U_{c_{2, t}} q_{t},
\end{gathered}
$$

where $\mu_{t}$ is the Lagrange multiplier associated with the borrowing constraint. ${ }^{20}$

Patient Lenders. Patient-lender households choose how much to consume, work, invest in housing, and invest in physical capital $k_{t}$ which is rented to firms at the rate $r_{t}^{k}$. They also receive the firm's profits $\phi_{t}$ and make one-period loans to borrowers. The budget constraint of the patient household is given by:

$$
c_{1, t}+I_{t}+q_{t}\left(h_{1, t}-h_{1, t-1}\right)+\frac{b_{1, t-1} R_{t-1}}{\pi_{t}}=b_{1, t}+w_{t} L_{1, t}+r_{t}^{k} k_{t-1}+\phi_{t}
$$

where $(1-n) b_{1, t-1}=-n b_{2, t-1}$. In other words, the aggregate bonds of patient households correspond to the aggregate loans of impatient households.

The law of motion for physical capital is given by:

$$
k_{t}=(1-\delta) k_{t-1}+[1-\underbrace{\frac{\psi}{2}\left(I_{t} / I_{t-1}-1\right)^{2}}_{S\left(I_{t} / I_{t-1}\right)}] I_{t},
$$

where $\delta$ is the depreciation rate and the function $S\left(I_{t} / I_{t-1}\right)$ reflects investment adjustment costs. In steady state $S(\cdot)=S^{\prime}(\cdot)=0$ and $S^{\prime \prime}(\cdot)>0$.

\footnotetext{
${ }^{20}$ Given that $\beta_{2}<\beta_{1}$, it is straightforward to show that equation (3) holds with equality at the deterministic steady state. As is common in the literature, we solve the model assuming that the constraint is always binding in a neighborhood around the steady state. See, for example, Iacoviello (2005) and Iacoviello and Neri (2010).
} 
The patient household's optimal choices are characterized by the following first-order conditions:

$$
\begin{aligned}
& -U_{L_{1, t}}=U_{c_{1, t}} w_{t} \\
& U_{c_{1, t}}=\beta_{1} R_{t} \widehat{E}_{1, t}\left[\frac{U_{c_{1, t+1}}}{\pi_{t+1}}\right] \text {, } \\
& U_{c_{1, t}} q_{t}=U_{h_{1, t}}+\beta_{1} \widehat{E}_{1, t}\left[U_{c_{1, t+1}} q_{t+1}\right] \text {, } \\
& U_{c_{1, t}} q_{t}^{k}=\beta_{1} \widehat{E}_{1, t}\left\{U_{c_{1, t+1}}\left[q_{t+1}^{k}(1-\delta)+r_{t+1}^{k}\right]\right\} \\
& U_{c_{1, t}}=U_{c_{1, t}} q_{t}^{k}\left[1-S\left(\frac{I_{t}}{I_{t-1}}\right)-\frac{I_{t}}{I_{t-1}} S^{\prime}\left(\frac{I_{t}}{I_{t-1}}\right)\right]+\left(\frac{I_{t}}{I_{t-1}}\right)^{2} \beta_{1} \widehat{E}_{1, t}\left[U_{c_{1, t+1}} q_{t+1}^{k} S^{\prime}\left(\frac{I_{t+1}}{I_{t}}\right)\right]
\end{aligned}
$$

where the last two equations represent the optimal choices of $k_{t}$ and $I_{t}$, respectively. The symbol $q_{t}^{k} \equiv v_{t} / U_{c_{1 t}}$ is the marginal value of installed capital with respect to consumption, where $v_{t}$ is the Lagrange multiplier associated with the capital law of motion (8). We interpret $q_{t}^{k}$ as the market value of claims to physical capital, i.e., the stock price.

\subsection{Firms and Price Setting}

Firms are owned by the patient households. We therefore assume that the subjective expectations of firms are formulated in the same way as their owners.

Final Good Production. There is a unique final good $y_{t}$ that is produced using the following constant returns-to-scale technology:

$$
y_{t}=\left[\int_{0}^{1} y_{t}(i)^{\frac{\theta-1}{\theta}} d i\right]^{\frac{\theta}{\theta-1}}, \quad i \in[0,1],
$$

where the inputs are a continuum of intermediate goods $y_{t}(i)$ and $\theta>1$ is the constant elasticity-of-substitution across goods. The price of each intermediate good $P_{t}(i)$ is taken as given by the firms. Cost minimization implies the following demand function for each good $y_{t}(i)=\left[P_{t}(i) / P_{t}\right]^{-\theta} y_{t}$, where the price index for the intermediate good is given by $P_{t}=\left[\int_{0}^{1} P_{t}(i)^{1-\theta} d i\right]^{1 /(1-\theta)}$.

Intermediate Good Production. In the wholesale sector, there is a continuum of firms indexed by $i \in[0,1]$ and owned by patient households. Intermediate goods-producing firms act in a monopolistic market and produce $y_{t}(i)$ units of each intermediate good $i$ using $L_{t}(i)=$ $(1-n) L_{1, t}(i)+n L_{2, t}(i)$ units of labor, according to the following constant returns-to-scale technology:

$$
y_{t}(i)=\exp \left(z_{t}\right) k_{t}(i)^{\alpha} L_{t}(i)^{1-\alpha},
$$


where $z_{t}$ is an $\operatorname{AR}(1)$ productivity shock.

We assume that intermediate firms adjust the price of their differentiated goods following the Calvo (1983) model of staggered price setting. Prices are adjusted with probability $1-\theta_{\pi}$ every period, leading to the following New Keynesian Phillips curve:

$$
\log \left(\frac{P_{t}}{P_{t-1}}\right)-\iota_{\pi} \log \left(\frac{P_{t-1}}{P_{t-2}}\right)=\beta_{1}\left[\widehat{E}_{1, t} \log \left(\frac{P_{t+1}}{P_{t}}\right)-\iota_{\pi} \log \left(\frac{P_{t}}{P_{t-1}}\right)\right]+\kappa_{\pi} \log \left(\frac{m c_{t}}{m c}\right)+u_{t}
$$

where $\kappa_{\pi} \equiv\left(1-\theta_{\pi}\right)\left(1-\beta \theta_{\pi}\right) / \theta_{\pi}$ and $\iota_{\pi}$ is the indexation parameter that governs the automatic price adjustment of non-optimizing firms. Variables without time subscripts represent steadystate values. The variable $m c_{t}$ represents the marginal cost of production and $u_{t}$ is an $\operatorname{AR}(1)$ cost-push shock. Cost minimization implies the following expression for marginal cost

$$
m c_{t}=\exp \left(-z_{t}\right)\left(\frac{w_{t}}{1-\alpha}\right)^{1-\alpha}\left(\frac{r_{t}^{k}}{\alpha}\right)^{\alpha} .
$$

\subsection{Monetary and Macroprudential Policy}

In the baseline model, we assume that the central bank follows a simple Taylor-type rule of the form:

$$
R_{t}=(1+r)\left(\frac{\pi_{t}}{1}\right)^{\alpha_{\pi}}\left(\frac{y_{t}}{y}\right)^{\alpha_{y}} \varsigma_{t},
$$

where $R_{t}$ is the gross nominal interest rate, $r=1 / \beta_{1}-1$ is the steady-state real interest rate, $\pi_{t} \equiv P_{t} / P_{t-1}$ is the gross inflation rate, $y_{t} / y$ is the proportional output gap, and $\varsigma_{t}$ is an $\operatorname{AR}(1)$ monetary policy shock.

In the policy experiments, we consider the following generalized policy rule that allows for a direct response to either house price growth or credit growth:

$$
R_{t}=(1+r)\left(\frac{\pi_{t}}{1}\right)^{\alpha_{\pi}}\left(\frac{y_{t}}{y}\right)^{\alpha_{y}}\left(\frac{q_{t}}{q_{t-4}}\right)^{\alpha_{q}}\left(\frac{b_{2, t}}{b_{2, t-4}}\right)^{\alpha_{b}} \varsigma_{t}
$$

where $q_{t} / q_{t-4}$ is the 4 -quarter growth rate in house prices (which equals the growth rate in the market value of the fixed housing stock) and $b_{2, t} / b_{2, t-4}$ is the 4-quarter growth rate of household debt, i.e., credit growth.

In the aftermath of the global financial crisis, a wide variety of macroprudential policy tools have been proposed to help ensure financial stability. ${ }^{21}$ For our purposes, we focus on policy variables that appear in the collateral constraint. For our first macroprudential policy experiment, we allow the regulator to adjust the value of the parameter $\gamma$ in equation (3). Lower values of $\gamma$ imply tighter lending standards. In the second macroprudential policy

\footnotetext{
${ }^{21}$ Galati and Moessner (2011) and the Bank of England (2011) provide comprehensive reviews of this literature.
} 
experiment, we consider a generalized version of the borrowing constraint which takes the form

$$
b_{2, t} \leq \frac{\widehat{\gamma}}{R_{t}}\left\{m w_{t} L_{2, t}+(1-m)\left[\widehat{E}_{1, t} q_{t+1} \pi_{t+1}\right] h_{2, t}\right\},
$$

where $m$ is the weight assigned by the lender to the borrower's wage income. Under this specification, $m=0$ corresponds to the baseline model where the lender only considers the expected value of the borrower's housing collateral. ${ }^{22}$ We interpret changes in the value of $m$ as being directed by the regulator. As $m$ increases, the regulator directs the lender to place more emphasis on the borrower's wage income when making a lending decision. Whenever $m>0$, we calibrate the value of the parameter $\widehat{\gamma}$ to maintain the same steady state loan-tovalue ratio as in the baseline version of the constraint (3). In steady state, we therefore have $\widehat{\gamma}=\gamma /\left[m w L_{2} /\left(q \pi h_{2}\right)+1-m\right]$, where $\widehat{\gamma}=\gamma$ when $m=0$. When $m>0$, the equilibrium loan-to-value ratio is no longer constant but instead moves in the same direction as the ratio of the borrower's wage income to housing collateral value. Consequently, the equilibrium loan-tovalue ratio will endogenously decline whenever the market value of housing collateral increases faster than the borrower's wage income. In this way, the generalized borrowing constraint acts like an automatic stabilizer to dampen fluctuations in household debt that are linked to excessive movements in house prices.

\subsection{Expectations}

Rational expectations are built on strong assumptions about agents' information. In actual forecasting applications, real-time difficulties in observing stochastic shocks, together with empirical instabilities in the underlying shock distributions could lead to large and persistent forecast errors. These ideas motivate consideration of a boundedly-rational forecasting algorithm, one that requires substantially less computational and informational resources. A long history in macroeconomics suggests the following adaptive (or error-correction) approach:

$$
\begin{aligned}
F_{t} X_{t+1} & =F_{t-1} X_{t}+\lambda\left(X_{t}-F_{t-1} X_{t}\right), \quad 0<\lambda \leq 1, \\
& =\lambda\left[X_{t}+(1-\lambda) X_{t-1}+(1-\lambda)^{2} X_{t-2}+\ldots\right],
\end{aligned}
$$

where $X_{t+1}$ is the object to be forecasted and $F_{t} X_{t+1}$ is the corresponding subjective forecast. In this model, $X_{t+1}$ is typically a nonlinear combination of endogenous and exogenous variables dated at time $t+1$. For example, in equation (5) we have $X_{t+1}=U_{c_{2, t+1}} / \pi_{t+1}$, whereas in equation (12) we have $X_{t+1}=U_{c_{1, t+1}}\left[q_{t+1}^{k}(1-\delta)+r_{t+1}^{k}\right]$. The term $X_{t}-F_{t-1} X_{t}$ is the

\footnotetext{
${ }^{22}$ The generalization of the borrowing constraint has an impact on the first-order conditions of the impatient households. In particular, the labor supply equation (4) is replaced by $-U_{L_{2 t}}=w_{t}\left[U_{c_{2 t}}+\widehat{\gamma} m \mu_{t}\right]$, where $\mu_{t}$ is the Lagrange multiplier associated with the generalized borrowing constraint.
} 
observed forecast error in period $t$. The parameter $\lambda$ governs the forecast response to the most recent data observation $X_{t}$. For simplicity, we assume that $\lambda$ is the same for both types of households.

Equation (21) implies that the forecast at time $t$ is an exponentially-weighted moving average of past observed values of the forecast object, where $\lambda$ governs the distribution of weights assigned to past observed values - analogous to the gain parameter in the adaptive learning literature. When $\lambda=1$, households employ a simple random walk forecast. By comparison, the "sticky-information" model of Mankiw and Reis (2002) implies that the forecast at time $t$ is based on an exponentially-weighted moving average of past rational forecasts. A sticky-information version of equation (21) could be written recursively as $F_{t} X_{t+1}=F_{t-1} X_{t}+\mu\left(E_{t} X_{t+1}-F_{t-1} X_{t}\right)$, where $\mu$ represents the fraction of households who update their forecast to the most-recent rational forecast $E_{t} X_{t+1}$.

For each of the model's first order conditions, we nest the moving-average forecast rule (21) together with the rational expectation $E_{t} X_{t+1}$ to obtain the following "hybrid expectation" which is a weighted-average of the two forecasts

$$
\widehat{E}_{j, t} X_{t+1}=\omega F_{t} X_{t+1}+(1-\omega) E_{t} X_{t+1}, \quad 0 \leq \omega \leq 1, \quad j=1,2,
$$

where $\omega$ can be interpreted as the fraction of households who employ the moving-average forecast rule (21). For simplicity, we assume that $\omega$ is the same for both types of households. In equilibrium, the fully-rational forecast $E_{t} X_{t+1}$ takes into account the influence of households who employ the moving-average forecast rule. In this way, the influence of the moving-average forecast rule on the behavior of endogenous variables is "leveraged up."

To sidestep issues about the long-term survival of agents who employ moving-average forecast rules, we rule out direct asset trading between these agents and agents with fullyrational expectations. Alternatively, we could interpret $\omega$ as the probability weight that a single agent type assigns to the moving-average rule when constructing a one-period-ahead forecast, along the lines of De Grauwe (2012). An extension of the model could allow the parameter $\omega$ to be time varying, depending on the recent performance of each forecasting rule, as in Brock and Hommes (1998) and De Grauwe (2012). We could also allow agents to adjust $\lambda$ over time to improve the performance of the moving-average forecast rule when evaluated over a window of recent data, as in Lansing (2009). Either setup would contribute to excess volatility of the model variables.

\section{Model Calibration}

Table 1 summarizes our choice of parameter values. Some parameters are set to achieve target values for steady-state variables while others are set to commonly-used values in the liter- 
ature. $^{23}$ The time period in the model is one quarter. The relative number of impatient households relative to patient households is $n=0.9$ so that patient households represent the top decile of households in the model economy. In the model, patient households own $100 \%$ of physical capital wealth. The top decile of U.S. households owns approximately $80 \%$ of financial wealth and about $70 \%$ of total wealth including real estate. Our setup implies a Gini coefficient for physical capital wealth of 0.90 . The Gini coefficient for financial wealth in U.S. data has ranged between 0.89 and 0.93 over the period 1983 to 2001. ${ }^{24}$ The production function exponent on capital $\alpha$ and the labor disutility parameters $\nu_{1, L}$ and $\nu_{2, L}$ are chosen simultaneously such that: (1) capital's share of total income (consisting of capital rental income plus firm profits) is $36 \%$ in steady state, (2) the top income decile (i.e., patient households) earns $40 \%$ of total income in steady state, and (3) the remaining agents (i.e., impatient households) earn $60 \%$ of total income in steady state. The $40 \%$ income share of the top decile is consistent with the long-run average measured by Piketty and Saez (2003). ${ }^{25}$ The elasticity parameter $\theta=33.33$ is set to yield a steady-state price mark-up of about $3 \%$.

The discount factor of patient households is set to $\beta_{1}=0.98$ such that the annualized net equity return in steady state is $r^{s}=4\left(1 / \beta_{1}-1\right) \simeq 8 \%$, consistent with the long-run real return on the S\&P 500 stock price index. The discount factor for impatient agents is set to $\beta_{2}=0.95$, thus generating a strong desire for borrowing. The investment adjustment cost parameter $\psi=5$ is in line with values typically estimated in DSGE models. Capital depreciates at a typical quarterly rate of $\delta=0.025$. The habit formation parameter is $b=0.7$. This value delivers a sufficient amount of variation in agents' stochastic discount factors to allow the hybrid expectations model to generate volatility in house prices that is reasonably close to that observed in U.S. data. The labor supply elasticity parameter is set to $\varphi_{L}=0.1$, implying a very flexible labor supply. The housing weights in the utility functions are set to $\nu_{1, h}=0.4$ and $\nu_{2, h}=0.1$ for the patient and impatient households, respectively. Our calibration implies that the top income decile of households derive a relatively higher per unit utility from housing services. Together, these values imply a steady-state ratio of total housing wealth to annualized GDP of 1.6. According to Iacoviello (2010), the corresponding ratio in U.S. data has the ranged between 1.2 and 2.3 over the period 1952 to 2008 .

The Calvo parameter $\theta_{\pi}=0.75$ and the indexation parameter $\iota_{\pi}=0.25$ represent typical values. The interest rate responses to inflation and quarterly output are $\alpha_{\pi}=1.5$ and $\alpha_{y}=$ 0.25 which are typical values for Taylor-type rules. The value $\alpha_{y}=0.25$ corresponds to a response coefficient of 1.0 on annualized output, consistent with the rule analyzed by Taylor (1999). The absence of explicit interest rate smoothing in the interest rate rule (18) justifies

\footnotetext{
${ }^{23}$ See, for example, Iacoviello and Neri (2010).

${ }^{24}$ See Wolff (2006), Table 4.2, p. 113.

${ }^{25}$ Updated data through 2010 are available from Emmanuel Saez's website.
} 
a value of $\rho_{\varsigma}=0.8$ for the persistence of the monetary policy shock.

The calibration of the forecast rule parameters $\omega$ and $\lambda$ requires a more detailed description. Our aim is to magnify the volatility of house prices and household debt while maintaining procyclical movement in both variables. We experimented with different combinations of $\omega$ and $\lambda$ to determine their influence on the volatility and co-movement of selected model variables. For some combinations, the number of explosive eigenvalues exceeded the number of predetermined variables, such that a unique stable equilibrium did not exist for that particular combination of $\omega$ and $\lambda$. The baseline calibration of $\omega=0.30$ and $\lambda=0.35$ delivers excess volatility in comparison to the rational expectations benchmark while maintaining pro-cyclical movement in house prices and household debt. Even though only $30 \%$ of households in the model employ a moving-average forecast rule, the presence of these agents influences the nature of the rational forecasts employed by the remaining $70 \%$ of households. ${ }^{26}$

For the generalized interest rate rule (19), we set $\alpha_{q}=0.2$ or $\alpha_{b}=0.2$ to illustrate the effects of a direct interest rate response to financial variables. The constant loan-to-value ratio in the baseline model is $\gamma=0.7$. This is consistent with the long-run average loan-to-value ratio of U.S. residential mortgage holders. ${ }^{27}$ In the generalized borrowing constraint (20), we set $m=0.75$ which requires the lender to place a substantial weight on the borrowers wage income. In this case, we set $\widehat{\gamma}=1.153$ to maintain the same steady state loan-to-value ratio as in the baseline model with $m=0$.

In the sensitivity analysis, we examine the volatility effects of varying the policy parameters over the following range of values: $\alpha_{q}, \alpha_{b} \in[0,0.3], \gamma \in[0.2,1.0]$, and $m \in[0,1.0]$.

\section{Excess Volatility}

In this section, we show that the hybrid expectations model generates excess volatility in the endogenous variables including asset prices and household debt in comparison to the same model under fully-rational expectations. The hybrid expectations model also delivers increased persistence of most endogenous variables while preserving the co-movement between house prices, household debt, and real output. In this way, the hybrid expectations model is better able to capture the patterns observed in many industrial countries over the past decade.

Figure 5 depicts simulated time series for the house price, household debt, the price of capital $q_{t}^{k}$ (which we interpret as a stock price index), aggregate real consumption, real output,

\footnotetext{
${ }^{26}$ Levine, et al. (2012) employ a specification for expectations that is very similar to our equations (21) and (22). However, their DSGE model omits house prices and household debt. They estimate the fraction of backward-looking agents ( $\omega$ in our model) in the range of 0.65 to 0.83 with a moving-average forecast parameter ( $\lambda$ in our model) in the range of 0.1 to 0.4 .

${ }^{27}$ We thank Bill Emmons of the Federal Reserve Bank of St. Louis for kindly providing this data, which are plotted in Figure 4.
} 
aggregate labor hours, inflation, and the policy interest rate $R_{t}$. All series are plotted as percent deviations from steady state values without applying any filter. The figure shows that the hybrid expectations model serves to magnify the volatility of the endogenous variables. This is not surprising given that the moving-average forecast rule (21) embeds a unit root assumption. This is most obvious when $\lambda=1$ but is also true when $0<\lambda<1$ because the weights on lagged variables sum to unity. ${ }^{28}$ Due to the self-referential nature of the equilibrium conditions, the households' subjective forecast influences the dynamics of the object that is being forecasted. ${ }^{29}$ Moreover, the use of moving-average forecast rules by a subset of agents serves to magnify the volatility of the fully-rational forecasts constructed by the remaining agents. The latter effect is an important channel that "leverages up" the influence of the agents who employ moving-average forecast rules. ${ }^{30}$

Table 2 compares the volatility of model-generated data to the standard deviations of loglinearly detrended data for U.S. real house prices, U.S. real household debt per capita, and U.S. real GDP per capita over the period 1987.Q3 to 2012.Q1. ${ }^{31}$ The hybrid expectations model outperforms the rational expectations model in being able to match the observed volatilities in the data. However, with only three exogenous shocks and no shocks to agents' preferences for housing services, the hybrid expectations model still somewhat underpredicts the volatility of U.S. house prices. The hybrid expectations model does capture the comovement of real output, house prices, and household debt that is observed in the data. This comovement can be observed in Figures 5 and 6 . The simulations mimic the evidence that in a period of economic expansion, a house price boom is accompanied by an increase in household debt, as the collateral constraint allows both to move up simultaneously.

Table 3 compares volatilities for a wider selection of model-generated series. Excess volatility in the hybrid expectations model is greatest for the household debt series which is magnified by a factor of 1.62 relative to the rational expectations benchmark. The volatility of house prices is magnified by a factor of 1.47 . House price volatility is magnified by less than debt

\footnotetext{
${ }^{28}$ Lansing (2010) considers the implications of a forecast rule with a perceived unit root in the context of a Lucas-type asset pricing model.

${ }^{29}$ A simple example with $\lambda=1$ illustrates the point. Suppose that the Phillips curve is given by $\pi_{t}=$ $\beta \widehat{E}_{t} \pi_{t+1}+\gamma y_{t}$, where $y_{t}$ follows an $\operatorname{AR}(1)$ process with persistence $\rho$ and $\widehat{E}_{t} \pi_{t+1}=\omega F_{t} \pi_{t+1}+(1-\omega) E_{t} \pi_{t+1}$. When $F_{t} \pi_{t+1}=\pi_{t}$, the equilibrium law of motion is $\pi_{t}=\gamma y_{t} /[1-\beta \omega-\rho \beta(1-\omega)]$ which implies $\operatorname{Var}\left(\pi_{t}\right)=$ $\gamma^{2} \operatorname{Var}\left(y_{t}\right) /[1-\beta \omega-\rho \beta(1-\omega)]^{2}$. When $\rho<1$, an increase in $\omega$ increases both $\operatorname{Var}\left(\pi_{t}\right)$ and the variance of the rational forecast $\operatorname{Var}\left(E_{t} \pi_{t+1}\right)$.

${ }^{30}$ Continuing with the example from the previous footnote, the magnification of the volatility of the rational forecast $E_{t} \pi_{t+1}$ is an important channel for leveraging up the influence of the backward-looking agents. If the rational, forward-looking agents ignored the presence of the backward-looking agents, then we would have $\pi_{t}=\gamma y_{t}(1-\rho \beta \omega) /[(1-\rho \beta)(1-\omega \beta)]$, which implies a smaller $\operatorname{Var}\left(\pi_{t}\right)$ for any $0<\omega<1$.

${ }^{31}$ The log-linear trends in Figure 1 are computed using a longer sample of data that starts in 1965.Q1. Given the long-run trend, the volatility statistics for the detrended data are computed for the shorter sample period which covers the combined terms of Fed Chairmen Greenspan, and Bernanke - a period of reasonably consistent monetary policy responses to inflation and real output.
} 
volatility because the patient-lender households do not use debt for the purchase of housing services. Stock price volatility is magnified by a factor of 1.35 . The volatility of labor hours is magnified by a factor of 1.35 whereas output volatility is magnified by a factor of 1.40 , and consumption volatility is magnified by a factor of 1.25 .

As noted in the introduction, countries with the largest increases in household leverage tended to experience the fastest run-ups in house prices from 1997 to 2007 . The same countries tended to experience the most severe declines in consumption once house prices started falling. The hybrid expectations model delivers the result that excess volatility in house prices and household debt also gives rise to excess volatility in consumption.

Table 4 shows that the persistence of model variables is higher under hybrid expectations. The autocorrelation coefficient for house prices goes from 0.82 under rational expectations to 0.91 under hybrid expectations. The autocorrelation coefficient for household debt goes from 0.68 to 0.83 . The increased persistence improves the model's ability to produce large swings in house prices and household debt, as was observed in many industrial countries over the past decade. The corresponding autocorrelation coefficients for detrended U.S. house prices and U.S. household debt per capita from Figure 1 are 0.96 and 0.99, respectively.

Figure 6 plots impulse response functions for a one-standard deviation technology shock which boosts aggregate productivity in accordance with equation (15). The resulting fluctuations in the hybrid expectations model tend to be more pronounced and longer lasting versus those in the rational expectations model. Although not shown, the hybrid expectations model also delivers more pronounced fluctuations in response to a cost push shock in equation (16) or a monetary policy shock in equation (18).

Figure 6 shows that the initial impact effect of the shock can be smaller under hybrid expectations for some variables. But over a longer horizon, all of the variables exhibit more pronounced fluctuations. According to Barberis, et al. (1998), real-world asset prices tend to underreact to fundamental developments over short horizons (1 to 12 months), but prices tend to overreact to fundamentals over longer horizons ( 3 to 5 years). This type of pattern can be observed for some variables under hybrid expectations. The use of a moving-average forecast rule introduces lagged variables which inhibit an immediate jump in agents' expectations upon impact of a shock. Depending on the composition of the nonlinear object being forecasted, this feature can dampen the immediate response of some variables. But over a longer horizon, the unit root assumption embedded in the moving-average forecast rule serves to magnify the amplitude of fluctuations by increasing the equilibrium persistence of the model variables. In this way, agents' perception of a unit root can become partially self-fulfilling. ${ }^{32}$

Barberis, et al. (1998) argue that the longer-run overreaction property of asset prices can

\footnotetext{
${ }^{32}$ This idea is explored more fully in Lansing (2009) where the moving average parameter $\lambda$ is pinned down by the concept of a "consistent expectations equilibrium."
} 
lead to significant overvaluation in response to a sequence of favorable fundamental shocks. Consistent with this idea, Shiller (2005) documents that major stock price run-ups have generally coincided with the introduction of some new technology that is generally perceived to herald a "new era." 33 With respect to the housing market, Feldstein (2007) makes a case that over-reliance by lenders on new statistical risk assessment models (a new technology) played a role in the mid-2000s U.S. housing market boom. According to Greenspan (2002), "Bubbles are often precipitated by perceptions of real improvements in the productivity and underlying profitability of the corporate economy. But as history attests, investors then too often exaggerate the extent of the improvement in economic fundamentals."

Central bank loss functions are often modeled as a weighted-sum of squared deviations of inflation and output from targets. In our model, such a loss function is equivalent to a weighted-sum of the unconditional variances of inflation and output since the target (or steady-state) values of both variables is zero. The results shown in Table 3 imply a higher loss function realization under hybrid expectations. As discussed further in the next section, a concern for financial stability might be reflected in an expanded loss function that takes into account the variance of household debt. In this case, the high volatility of household debt observed under hybrid expectations would imply an even higher loss function realization and hence a stronger motive for central bank stabilization policy.

\section{$5 \quad$ Policy Experiments}

In this section, we evaluate various policy actions that might be used to dampen excess volatility in the hybrid expectations model. We first examine the merits of a direct response to either house price growth or household debt growth (i.e., credit growth) in the central bank's interest rate rule. Next, we analyze the use of two macroprudential policy tools that affect the borrowing constraint, i.e., a permanent reduction in the loan-to-value ratio and a policy that directs lenders to place increased emphasis on the borrower's wage income in determining how much they can borrow.

\subsection{Interest Rate Response to House Price Growth or Credit Growth}

The generalized interest rate rule (19) allows for a direct response to either house price growth credit growth. As an illustrative case, Table 5 shows the results when the central bank responds to the selected financial variable with a coefficient of $\alpha_{q}=0.2$ or $\alpha_{b}=0.2$. For this exercise, we hold the response coefficients on inflation and output constant at their baseline values of $\alpha_{\pi}=1.5$ and $\alpha_{y}=0.25$.

\footnotetext{
${ }^{33}$ Major stock price run-ups occurred in the early 1900s (high speed rail travel), the 1920s (mass-production of automobiles), the 1960s (television and space travel), and the late 1990s (internet-based business model).
} 
The top panel of Table 5 shows that under rational expectations, responding to house prices mildly decreases the volatility of consumption but mildly increases the volatilities of output and inflation relative to the no-response version of the same model. The volatility of labor hours is magnified by a factor of 1.15. These results are in line with Iacoviello (2005) who finds no significant stabilization benefits for an interest rate response to the level of house prices in a rational expectations model. The largest stabilization effects under rational expectations are achieved with household debt and the price of capital, which exhibit volatility ratios of 0.95 and 0.94, respectively. Under hybrid expectations, responding to house price growth magnifies the volatility of all variables except household debt (volatility ratio of 0.95 ). Moreover, the undesirable magnification of inflation volatility is now quantitatively much larger - exhibiting a volatility ratio of 1.18 .

Our results show that by moving the interest rate in response to a variable (house price growth) that exhibits excess volatility, the central bank can transmit the excess volatility to other endogenous variables. Another factor is that an interest rate response to house price growth has differing effects, depending on whether households are borrowers or lenders. ${ }^{34}$ Only impatient households use debt for the purchase of housing services. Making borrowing more costly for impatient households simultaneously makes lending more profitable for patient households. These offsetting effects can shift the demand for housing in such a way that house price volatility and household debt volatility need not respond in the same direction to a given policy rule change.

The bottom panel of Table 5 shows the results for an interest rate response to credit growth. Under rational expectations, the results are similar to an interest rate response to house price growth except that the stabilization effects on household debt are improved (volatility ratio of 0.54). But under hybrid expectations, responding to credit growth performs poorly. Specifically, inflation volatility is magnified by a factor of 1.63 and there is no compensating reduction in the volatility of household debt. On the contrary, debt volatility is somewhat magnified by a factor of 1.08 , as is the volatility of labor hours. These results demonstrate that the stabilization benefits of a particular monetary policy can be influenced by the nature of agents' expectations. Under rational expectations, the impatient households understand that an increase in borrowing will contribute to higher interest rates which in turn, will raise the cost of borrowing. This expectations channel serves to dampen fluctuations in household debt. ${ }^{35}$ But under hybrid expectations, this channel becomes less effective because a subset of borrowers construct forecasts using only a moving-average of past values and hence do not take into account the central bank's policy rule.

\footnotetext{
${ }^{34}$ Suh (2012) makes a similar point in the context of a rational expectations model.

${ }^{35} \mathrm{Suh}(2012)$ also finds that an interest rate response to credit can reduce credit volatility in a rational expectations model. In his model, this result comes at the expense of significantly higher inflation volatility.
} 
Figures 7 and 8 plot the results for the hybrid expectations model when we allow $\alpha_{q}$ or $\alpha_{b}$ to vary from a low 0 to a high of 0.3 . As either $\alpha_{q}$ or $\alpha_{b}$ increase, the policy ends up magnifying the volatility of output, consumption, labor hours, and inflation, with the undesirable effect on inflation being more severe when responding to credit growth. In the lower right panel of the figure, we plot the realized values of two illustrative loss functions that are intended to represent plausible stabilization goals of a central bank. Loss function 1 is a commonly-used specification consisting of an equal-weighted sum of the unconditional variances of inflation and output. Loss function 2 includes an additional term not present in loss function 1, namely, the unconditional variance of household debt which is assigned a relative weight of 0.25 . We interpret the additional term as reflecting the central bank's concern for financial stability. Here, we link the concern for financial stability to a variable that measures household leverage whereas Woodford (2011) links this concern to a variable that measures financial sector leverage.

Figures 7 and 8 show that responding to either house price growth or credit growth is detrimental from the standpoint of loss function 1. However, in light of the severe economic fallout from the recent financial crisis, views regarding the central bank's role in ensuring financial stability appear to be shifting. ${ }^{36}$ From the standpoint of loss function 2, an interest rate response to house price growth achieves a small success in slightly reducing loss function 2 . In contrast, an interest rate response to credit growth remains detrimental under loss function 2 because the policy tends to magnify fluctuations in household debt.

As a caveat to the above results, we acknowledge that the response coefficients of the generalized interest rate rule (19) have not been optimized with respect to any utility function or loss function. The thought experiment we have in mind involves a modest shift from current central bank policy (which we interpret as being captured by equation (18) with $\alpha_{\pi}=1.5$ and $\left.\alpha_{y}=0.25\right)$ to a policy that responds to a financial variable which previously was not included in the interest rate rule. If such a policy shift were to be undertaken by a real-world central bank, we think it is unlikely that policymakers would see fit to substantially alter their responses to inflation and output at the same time.

It is not obvious whether the presence of some backward-looking agents would magnify or attenuate the optimal response coefficients relative to the same model under fully-rational expectations. Lansing and Trehan (2003) examine the influence of the degree of rational forward-looking behavior on the magnitude of the optimal interest rate response coefficients in small scale New Keynesian model without capital. They show analytically that a more forward-

\footnotetext{
${ }^{36}$ In the words of San Francisco Fed President Janet Yellen (2009), "What has become patently obvious is that not dealing with certain kinds of bubbles before they get big can have grave consequences. This lends more weight to arguments in favor of attempting to mitigate bubbles, especially when a credit boom is the driving factor." Malliaris (2012) reviews the evidence of a shift in central bank policy thinking in favor of leaning against suspected bubbles.
} 
looking aggregate demand equation serves to attenuate the optimal responses to inflation and the output gap in the policy rule. A more forward-looking Phillips curve serves to attenuate the optimal response to inflation but magnifies the optimal response to the output gap. ${ }^{37}$ The overall impact on the optimal response coefficients will thus depend on the model calibration, specifically the fraction of agents who are assumed to employ either backward- or forwardlooking expectations in each of the various model equations.

While an exploration of optimal monetary policy is beyond the scope of this paper, such an exploration might identify some stabilization or welfare benefits to responding to either house price growth or credit growth. We note that in the case of hybrid expectations, the lagged expectation of backward-looking agents (i.e., the lagged moving average of the forecast object) would represent an additional state variable that would appear in the central bank's fully-optimal policy rule.

\subsection{Tightening of Lending Standards: Decrease LTV}

The top panel of Table 6 shows the results for a macroprudential policy that permanently tightens lending standards by reducing the maximum loan-to-value ratio $\gamma$ in equation (3) from 0.7 to 0.5 . Under both rational and hybrid expectations, the policy succeeds in reducing the volatility of household debt.

More generally, Figure 9 plots the results for hybrid expectations when we allow $\gamma$ to vary from a low 0.2 to a high of 1.0. The figure shows that lower values of $\gamma$ (implying tighter lending standards) help reduce the volatilities of house prices and household debt, but output volatility is magnified. The volatility effects on other variables are generally small.

On the one hand, a tightening of lending standards can help stabilize house prices and household debt and thereby help promote financial stability. But on the other hand, permanently restricting access to borrowed money will impair the ability of impatient households to smooth their consumption, possibly magnifying the volatility of aggregate consumption, as well as output and labor hours.

In the lower right panel of Figure 9, we see that a decrease in $\gamma$ starting from 0.7 is approximately neutral from the standpoint of loss function 1 which only considers output and inflation. However, the same policy is beneficial from the standpoint of loss function 2 which takes into account financial stability via fluctuations in household debt. Under these circum-

\footnotetext{
${ }^{37} \mathrm{~A}$ more forward-looking aggregate demand equation means that the output gap can exhibit a morepronounced jump in response to a change in the policy interest rate. The enhanced impact of the policy rate allows the output gap to be brought back to zero (the central bank's target level) with a smaller interest rate response. Improved control over the output gap allows inflation to be brought back to target with a smaller response as well. A more forward-looking Phillips curve implies that future inflation is determined less by current inflation and more by the current output gap. The optimal response, then, is for the central bank to react less to inflation and more to the output gap.
} 
stances, a decision by regulators to tighten lending standards could be met with opposition from those who do not share the regulator's concern for financial stability.

\subsection{Wage Income in the Borrowing Constraint}

A basic problem with loan-to-value constraints is that the denominator (i.e., value) is subject to bubble-induced distortions. During the U.S. housing boom of the mid-2000s, standard loanto-value ratios provided no significant warning of an excessive run-up in household leverage because debt and housing values rose together in a self-reinforcing feedback loop. Later, however, after housing values collapsed, a painful deleveraging was forced upon households which continues to impose a significant drag on consumer spending and real economic growth nearly four years after the official end date of the Great Recession.

Figure 10 compares the volatility of the borrower's wage income to the volatility of the borrower's housing value in the rational expectations model and the hybrid expectations model. When expectations are fully-rational, the volatilities of the two series are roughly similar, so it does not make much difference which one is included in the collateral constraint. However, when expectations are not fully-rational, the volatility of the borrower's housing value is much larger than the volatility of the borrower's wage income. In this case, excess volatility in housing value is transmitted directly to excess volatility in household debt, which is harmful from a financial stability perspective. In a world where asset prices exhibit excess volatility, agents could potentially benefit if lending decisions were made on the basis of the borrower's wage income, which is less subject to bubble-induced distortions than housing value.

The bottom panel of Table 6 shows the results for a macroprudential policy that requires lenders to place a substantial emphasis on the borrower's wage income in the borrowing constraint. Specifically, we set $m=0.75$ in equation (20) with $\widehat{\gamma}=1.153$ so as to leave the steady-state loan-to-value ratio unchanged from the baseline model with $m=0$.

Under both expectations regimes, the policy succeeds in reducing the volatility of household debt. Under rational expectations, the volatility of household debt is reduced by a factor of 0.66. Under hybrid expectations, debt volatility is reduced by a factor 0.51 . The volatility effects on the other variables are generally quite small, but under hybrid expectations, volatilities with $m=0.75$ are mostly lower relative to the case with $m=0$.

Taken together, the top and bottom panels of Table 6 show that a change in either of the two macroprudential policy parameters $(\gamma$ or $m$ ) primarily affects the volatility of household debt, with only small impacts on the volatilities of the other model variables. This result is perhaps not surprising given that (1) the aggregate housing stock is fixed and does not enter as an input to production, and (2) the weights on housing services in agents' utility functions are small in comparison to the weights on consumption and leisure - consistent with empirical 
estimates of these parameters. Using a model that is similar to ours in many respects, Iacoviello and Neri (2010) estimate that housing collateral constraints account for only about 6 to 12 percent of the total variance of annual U.S. consumption growth over the past forty years, with the effect becoming a bit stronger in the post-1990 sample period. Nevertheless, the severe economic fallout from the recent U.S. housing bust suggests that allowing for nonlinearities in the modeling of collateral constraints (along the lines of Bianchi and Mendoza 2010, for example) is an important feature that is missing from our analysis.

Figure 11 plots the results for hybrid expectations when we allow $m$ to vary from a low of zero (representing a pure loan-to-value constraint) to a high of 1.0 (representing a pure debt-toincome constraint). As $m$ increases, the policy achieves reductions in the volatilities of house prices, household debt, the price of capital, consumption, labor hours, and inflation. Output volatility is only slightly magnified. Notably, the policy avoids the undesirable magnification of inflation volatility that was observed in the two interest rate policy experiments. In this sense, the present policy can be viewed as superior simply because it avoids doing harm. In the lower right panel of the figure, we see that an increase in $m$ achieves small stabilization benefits from the standpoint of loss function 1, but much larger benefits from the standpoint of loss function 2 .

Figure 12 shows that the generalized borrowing constraint with $m=0.75$ induces endogenous countercyclicality of the loan-to-value ratio. In this way, the policy serves as an "automatic stabilizer" for household debt. The intuition for this result is straightforward. Dividing both sides of equation (20) by $\left[\widehat{E}_{1, t} q_{t+1} \pi_{t+1}\right] h_{2 t} / R_{t}$ we obtain

$$
\frac{b_{2 t} R_{t}}{\left[\widehat{E}_{1, t} q_{t+1} \pi_{t+1}\right] h_{2 t}} \leq \widehat{\gamma}\left\{\frac{m w_{t} L_{2 t}}{\left[\widehat{E}_{1, t} q_{t+1} \pi_{t+1}\right] h_{2 t}}+1-m\right\}
$$

where the left-side variable is the equilibrium loan-to-value ratio plotted in Figure 12. When $m=0$, the left-side variable is constant. However when $m>0$, the left-side variable will move down if the lender's expected collateral value $\left[\widehat{E}_{1, t} q_{t+1} \pi_{t+1}\right] h_{2 t}$ is increasing faster than the borrower's wage income $w_{t} L_{2, t}$. The figure shows that the endogenous countercyclicality is stronger under hybrid expectations.

U.S. housing values rose faster than wage income during the boom years of the mid-2000s. Unfortunately, lenders did not react by tightening lending standards as called for by a constraint such as (23). On the contrary, lending standards deteriorated as the boom progressed. Instead of placing a substantial weight on the borrower's income in the underwriting decision, lenders increasingly approved mortgages with little or no documentation of income. ${ }^{38}$

\footnotetext{
${ }^{38}$ According to the U.S. Financial Crisis Inquiry Commission (2011), p. 165, "Overall, by 2006, no-doc or low-doc loans made up $27 \%$ of all mortgages originated."
} 
As mentioned in the introduction, a number of recent papers have explored the stabilization benefits of countercyclical loan-to-value rules in rational expectations models. While it may be possible to successfully implement such state-contingent rules within a regulatory framework, it seems much easier and more transparent for regulators to simply mandate a substantial emphasis on the borrower's wage income in the lending decision.

A cross-country study by Lim, et al. (2011) provides empirical support for our findings. The authors compare the use and performance of loan-to-value constraints versus debt-toincome constraints together with other macroprudential policy tools. Their regression results (p. 53) show that the implementation of a debt-to-income cap is more effective than a loanto-value cap in reducing the growth rates of real estate prices and credit, consistent with our model simulations.

\section{Conclusion}

There are many examples in history of asset prices exhibiting sustained run-ups that are difficult to justify on the basis of economic fundamentals. Excessive run-ups in asset prices can have important consequences for the economy as firms and investors respond to the price signals, potentially resulting in capital misallocation. ${ }^{39}$ The typical transitory nature of these run-ups should perhaps be viewed as a long-run victory for fundamental asset pricing theory. Still, it remains a challenge for fundamental theory to explain the ever-present volatility of asset prices within a framework of efficient markets and fully-rational agents.

This paper showed that the introduction of simple moving-average forecast rules for a subset of agents can significantly magnify the volatility and persistence of house prices and household debt relative to an otherwise similar model with fully-rational agents. A wide variety of empirical evidence supports the idea that expectations are often less than fully-rational. One obvious example can be found in survey-based measures of U.S. inflation expectations which are well-captured by a moving average of past inflation rates. A moving-average forecast rule can also be justified as an approximation to a standard Kalman filter algorithm in which the forecast variable is subject to both permanent and temporary shocks.

The extensive harm caused by the financial crisis raises the question of whether policymakers could have done more to prevent the buildup of dangerous financial imbalances, particularly in the household sector. The U.S. Financial Crisis Inquiry Commission (2011) concluded, "Despite the expressed view of many on Wall Street and in Washington that the crisis could not have been foreseen or avoided, there were warning signs. The tragedy was that they were ignored or discounted. There was an explosion in risky subprime lending and securitization,

\footnotetext{
${ }^{39}$ Lansing (2012) examines the welfare consequences of speculative bubbles in a model where excessive asset price movements can affect the economy's trend growth rate.
} 
an unsustainable rise in housing prices, widespread reports of egregious and predatory lending practices, dramatic increases in household mortgage debt. . among many other red flags. Yet there was pervasive permissiveness; little meaningful action was taken to quell the threats in a timely manner. The prime example is the Federal Reserve's pivotal failure to stem the flow of toxic mortgages, which it could have done by setting prudent mortgage-lending standards." In the aftermath of the crisis, there remain important unresolved questions about whether regulators should attempt to lean against suspected bubbles and if so, what policy instruments should be used to do so.

This paper evaluated the performance of some monetary and macroprudential policy tools as a way of dampening excess volatility in a DSGE model with housing. While no policy tool was perfect, some performed better than others. A direct response to either house price growth or credit growth in the central bank's interest rate rule had the serious drawback of substantially magnifying the volatility of inflation. A tightening of lending standards, in the form of a lower LTV ratio, mildly raised the volatilities of some variables, but was successful in reducing the volatilities of house prices and household debt - a benefit from a financial stability perspective. The best-performing policy was one that required lenders to place a substantial weight on the borrower's wage income in the borrowing constraint. This policy contributed to both economic and financial stability; it mildly reduced the volatilities of most variables including house prices, while at the same time it substantially reduced fluctuations in household debt.

Interestingly, the most successful stabilization policy in our model calls for lending behavior that is basically the opposite of what was observed during the U.S. housing boom of the mid2000s. As the boom progressed, U.S. lenders placed less emphasis on borrowers' wage income and more emphasis on expected future house prices. So-called "no-doc" and "low-doc" loans became increasingly popular. Loans were approved that could only perform if house prices continued to rise, allowing borrowers to refinance. In retrospect, it seems likely that stricter adherence to prudent debt-to-income guidelines would have forestalled much of the housing boom, such that the subsequent reversal and the resulting financial turmoil would have been far less severe. 


\section{References}

Adam, K., P. Kuang, and A. Marcet 2012 House price booms and the current account, in D. Acemoglu and M. Woodford, (eds.), NBER Macroeconomics Annual 2011. Chicago: University of Chicago Press, pp. 77-122.

Airaudo, M., R. Cardani, and K.J. Lansing 2013 Monetary policy and asset prices with beliefdriven fluctuations, Journal of Economic Dynamics and Control, forthcoming.

Akram, Q. F. and Ø. Eitrheim 2008 Flexible inflation targeting and financial stability: Is it enough to stabilize inflation and output? Journal of Banking and Finance 32, 1242-1254.

Angelini, P., S. Neri, and F. Panetta 2010 Macroeconomic stabilization policies: Grafting macroprudential tools in a macroeconomic framework, Bank of Italy, Working Paper.

Bank of England 2011 Instruments of macroprudential policy, Discussion Paper (December).

Barberis, N., A. Shleifer, and R.W. Vishny 1998 A model of investor sentiment, Journal of Financial Economics 49, 307-343.

Bernanke, B.S. and M. Gertler 2001 Should central banks respond to movements in asset prices? American Economic Review, Papers and Proceedings 91, 253-257.

Bianchi, J. and E.G. Mendoza 2010 Overborrowing, financial crises, and macroprudential taxes, National Bureau of Economic Research Working Paper 16091.

Borio, C. and P. Lowe 2002 Asset prices, financial and monetary stability: Exploring the nexus, Bank for International Settlements Working Paper 114.

Brock, W.A. and C.H. Hommes 1998 Heterogenous beliefs and routes to chaos in a simple asset pricing model, Journal of Economic Dynamics and Control 22, 1235-1274.

Calvo, G.A. 1983 Staggered prices in a utility maximizing framework, Journal of Monetary Economics 12, 383-398.

Campbell, S., M.A. Davis, J. Gallin, and R.F. Martin 2009 What moves housing markets: A variance decomposition of the price-rent ratio, Journal of Urban Economics 66, 90-102.

Carroll, C. 2003 Macroeconomic expectations of households and professional forecasters, Quarterly Journal of Economics 118, 269-298.

Case, K.E., R.J. Shiller, and A. Thompson 2012 What have they been thinking? Home buyer behavior in hot and cold markets, NBER Working Paper 18400.

Cecchetti, S.G., H. Genberg, and S. Wadhwani 2002. Asset prices in a flexible inflation targeting framework, in W. C. Hunter, G. G. Kaufman and M. Pomerleano, eds., Asset Price Bubbles: Implications for Monetary, Regulatory, and International Policies. Cambridge, MA: MIT Press.

Christensen, I. and C.A. Meh 2011 Countercyclical loan-to-value ratios and monetary policy, Bank of Canada, Working Paper.

Christiano, L., C. Ilut, R. Motto, and M. Rostagno 2010 Monetary policy and stock market booms, in Federal Reserve Bank of Kansas City Economic Policy Symposium, Macroeconomic Challenges: The Decade Ahead.

Chow, G.C. 1989 Rational versus adaptive expectations in present value models, Review of Economics and Statistics 71, 385-393.

Coibion, O. and Y. Gorodnichencko 2012 What can survey forecasts tell us about informational rigidities? Journal of Political Economy 120, 116-159.

Committee on International Economic and Policy Reform 2011 Rethinking central banking, Brookings Institution Report (September). 
Davis, M.A., A. Lehnert, and R.F. Martin 2008, The rent-price ratio for the aggregate stock of owner-occupied housing, Review of Income and Wealth 54, 279-284.

De Grauwe, P. 2012 Booms and busts: New Keynesian and behavioral explanations, Journal of Economic Behavior and Organization 83, 484-501.

Dell'Ariccia, G,. D. Igan, and L. Laeven 2011 Credit booms and lending standards: Evidence from the subprime mortgage market, Journal of Money Credit and Banking 44, 367-384.

Drehmann, M., C. Borio, and K. Tsatsaronis 2012 Characterizing the financial cycle: Don't lose sight of the medium term, Bank for International Settlements Working Paper 380.

Dupor, B. 2005 Stabilizing non-fundamental asset price movements under discretion and limited information, Journal of Monetary Economics 52, 727-747.

Eusepi, S. and B. Preston 2011 Expectations, learning, and business cycle fluctuations, American Economic Review 101, 2844-2872.

Evans, G.W. and S. Honkapohja 2001 Learning and expectations in economics. Princeton: Princeton University Press.

Evans, G.W. and G. Ramey 2006 Adaptive expectations, underparameterization, and the Lucas critique, Journal of Monetary Economics 53, 249-264.

Feldstein, M.S. 2007 Housing, credit markets, and the business cycle, NBER Working Paper 13471.

Fischer, I. 1933 The debt-deflation theory of great depressions, Econometrica 1, 337-357.

Filardo, A. 2008 Household debt, monetary policy, and financial stability: Still searching for a unifying model, Bank for International Settlements, Research Paper.

Galati, G. and R. Moessner 2011 Macroprudential policy, A literature review, Bank for International Settlements, Working Paper 337.

Gelain, P. and K.J. Lansing 2013 House prices, expectations, and time-varying fundamentals, Norges Bank, Working Paper.

Gilchrist, S. and J.V. Leahy 2002 Monetary policy and asset prices, Journal of Monetary Economics 49, 75-97.

Gilchrist, S. and M. Saito 2008 Expectations, asset prices, and monetary policy: The role of learning, in J.Y Campbell, (ed.), Asset Prices and Monetary Policy. Chicago: University of Chicago Press, pp. 45-102.

Gertler, M. N. Kiyotaki, and A. Queralto 2012 Financial crisis, bank risk exposure, and government financial policy, Journal of Monetary Economics, forthcoming.

Glick, R. and K.J. Lansing 2010 Global household leverage, house prices and consumption, Federal Reserve Bank of San Francisco Economic Letter 2010-01 (January 11).

Goetzmann, W.N., L. Peng and J. Yen 2012 The subprime crisis and house price appreciation, Journal of Real Estate Finance and Economics 44, 36-56.

Granziera, E. and S. Kozicki 2012 House price dynamics: Fundamentals and expectations, Bank of Canada Working Paper 2012-12.

Greenspan, A., 2002 Economic volatility. Remarks at a symposium sponsored by the Federal Reserve Bank of Kansas City, Jackson Hole, Wyoming, August 30.

Greenspan, A. 2004a The mortgage market and consumer debt, Remarks at Community Bankers Annual Convention, Washington D.C. (October 19).

Greenspan, A., 2004b Understanding household debt obligations. Remarks at the Credit Union National Association 2004 Governmental Affairs Conference, Washington, D.C. (February 23). 
Greenwood, R. and A. Shleifer 2013 Expectations of returns and expected returns, NBER Working Paper 18686.

Himmelberg, C., C. Mayer, and T. Sinai 2005 Assessing high house prices: Bubbles, fundamentals, and misperceptions, Federal Reserve Bank of New York, Staff Report Number 218 (September).

Huang, K., Z. Liu, and T. Zha 2009 Learning, adaptive expectations, and technology shocks, Economic Journal 119, 377-405.

Huh, C.G. and K.J. Lansing 2000 Expectations, credibility, and disinflation in a small macroeconomic model, Journal of Economics and Business 51, 51-86.

Iacoviello, M. 2005 House prices, borrowing constraints, and monetary policy in the business cycle, American Economic Review, 95, 739-764.

Iacoviello, M. 2010 Housing in DSGE models: Findings and new directions, in O. de Bandt, T. Knetsch, J. Peñalosa, and F. Zollino, (eds.), Housing Markets in Europe: A Macroeconomic Perspective. Berlin, Hidelberg: Springer-Verlag, pp. 3-16.

Iacoviello, M. and S. Neri 2010 Housing market spillovers: Evidence from an estimated DSGE model, American Economic Journal: Macroeconomics 2, 125-164.

International Monetary Fund 2009 Lessons for monetary policy from asset price fluctuations, Chapter 3 of World Economic Outlook (WEO), Crisis and Recovery (October).

International Monetary Fund 2012 Dealing with household debt, Chapter 3 of World Economic Outlook (WEO), Growth Resuming, Dangers Remain (April).

Jurgilas, M. and K.J. Lansing 2013 Housing bubbles and expected returns to home ownership: Lessons and policy implications, in M. Balling and J. Berg, (eds.), Property Prices and Real Estate Financing in a Turbulent World. Société Universitaire Européenne de Recherches Financières (SUERF), forthcoming.

Kannan, P., P. Rabanal, and A. Scott 2012 Monetary and macroprudential policy rules in a model with house price booms, The B.E. Journal of Macroeconomics 12 (1), (Contributions), Article 16.

King, M. 1994 Debt deflation: Theory and evidence, European Economic Review 38, 419-445.

King, M. 2012 Twenty years of inflation targeting, Stamp Memorial Lecture at London School of Economics, Bank of England (October 9).

Kocherlakota, N. 2009 Modern macroeconomic models as tools for economic policy, Federal Reserve Bank of Minneapolis, The Region, pp. 5-21.

Kohn, D.L. 2004 Monetary policy and imbalances. Remarks at the Banking and Finance Lecture Series, Widener University, Chester, Pennsylvania, April 1.

Lambertini, L., C. Mendicino, and M.T. Punzi 2011 Leaning against boom-bust cycles in credit and housing prices, Working Paper.

Lansing, K.J. and B. Trehan 2003 Forward-looking behavior and optimal discretionary monetary policy, Economics Letters 81, 249-256.

Lansing, K.J. 2008 Monetary policy and asset prices, Federal Reserve Bank of San Francisco Economic Letter 2008-34 (October 31).

Lansing, K.J. 2009 Time-varying U.S. inflation dynamics and the New Keynesian Phillips curve, Review of Economic Dynamics 12, 304-326.

Lansing, K.J. 2010 Rational and near-rational bubbles without drift, Economic Journal 120, 1149-1174. 
Lansing, K.J. 2011 Gauging the impact of the great recession, Federal Reserve Bank of San Francisco Economic Letter 2011-21 (July 11).

Lansing, K.J. 2012 Speculative growth, overreaction, and the welfare cost of technology-driven bubbles, Journal of Economic Behavior and Organization 83, 461-483.

Lansing, K.J. and LeRoy, S.F., 2012. Risk aversion, investor information, and stock market volatility. Federal Reserve Bank of San Francisco Working Paper 2010-24.

LeRoy, S.F. and Porter, R.D., 1981. The present-value relation: Tests based on implied variance bounds. Econometrica 49, 555-577.

Levine, P., J. Pearlman, G. Perendia and B.Yang 2012 Endogenous persistence in an estimated DSGE model under imperfect information, Economic Journal 122, 1287-1312.

Lim, C., F. Columba, A. Costa, P. Kongsamut, A. Otani, M. Saiyid, T. Wezel, and X. Wu. 2011 Macroprudential policy: What instruments and how to use them? IMF Working Paper $11 / 238$.

Malliaris, A.G. 2012 Asset price bubbles and central bank policies: The crash of the Jackson Hole consensus, in D.D. Evanoff, G.G. Kaufman, and A.G. Malliaris, (eds.), New Perspectives on Asset Price Bubbles: Theory, Evidence and Policy. Oxford: Oxford University Press, pp. 407-432.

Mankiw, N.G. and R. Reis 2002 Sticky information versus sticky prices: A proposal to replace the New Keynesian Phillips curve, Quarterly Journal of Economics 117, 1295-1328.

Mankiw, N.G., R. Reis, and J. Wolfers 2004 Disagreement about inflation expectations, in M. Gertler and K. Rogoff, eds., NBER Macroeconomics Annual 2003. Cambridge MA: MIT Press, pp. 209-248.

McCarthy, J. and R. Peach 2004 Are home prices the next bubble? Federal Reserve Bank of New York, Economic Policy Review 10(3), 1-17.

Mehra Y.P. 2002 Survey measures of expected inflation: Revisiting the issues of predictive content and rationality, Federal Reserve Bank of Richmond Economic Quarterly 88/3, 17-36.

Mian, A. and A. Sufi 2009 The consequences of mortgage credit expansion: Evidence from the U.S. mortgage default crisis, Quarterly Journal of Economics 124, 1449-1496.

Mian, A. and A. Sufi 2010 Household leverage and the recession of 2007 to 2009, IMF Economic Review 58, 74-117.

Mian, A. and A. Sufi 2012 What explains high unemployment? The aggregate demand channel, NBER Working Paper 17830.

Milani, F. 2007 Expectations, learning and macroeconomic persistence, Journal of Monetary Economics 54, 2065-2082.

Muth, J.F. 1960 Optimal properties of exponentially weighted forecasts, Journal of the American Statistical Association 55, 299-306.

Nerlove, M. 1983 Expectations, plans, and realizations in theory and practice, Econometrica 51, 1251-1279.

Orphanides, A. and J.C. Williams 2005 Imperfect knowledge, inflation expectations, and monetary policy, in B. Bernanke and M. Woodford (eds.), The Inflation Targeting Debate. Chicago: University of Chicago Press, pp. 201-234.

Orphanides, A. and J.C. Williams 2009 Imperfect knowledge and the pitfalls of optimal control monetary policy, in K. Schmidt-Hebbel and C. Walsh (eds.), Central Banking, Analysis and Economic Policies: Monetary Policy Under Uncertainty and Learning 13, Central Bank of 
Chile, pp. 115-144.

Pavlov, A. and S. Wachter 2011 Subprime lending and real estate prices, Real Estate Economics 39, pp. 1-17.

Persons, C.E. 1930 Credit Expansion 1920 to 1929 and its lessons, Quarterly Journal of Economics 45, 94-130.

Piketty, T. and E. Saez 2003 Income inequality in the United States, 1913-1998, Quarterly Journal of Economics 118, 1-39.

Potter S. 2011 The failure to forecast the Great Recession, Federal Reserve Bank of New York, Liberty Street Economics Blog (November 25).

Reinhart, C.M. and V.R. Reinhart 2010 After the fall, Federal Reserve Bank of Kansas City Economic Policy Symposium, Macroeconomic Challenges: The Decade Ahead.

Roberts, J. 1997 Is inflation sticky? Journal of Monetary Economics 39, 173-196.

Roxburgh, C., S. Lund, T. Daruvala, J. Manyika, R. Dobbs, R. Forn, and K. Croxson 2012 Debt and deleveraging: Uneven progress on the path to growth, McKinsey Global Institute.

Sargent, T.J. 1996 Expectations and the nonneutrality of Lucas, Journal of Monetary Economics 37, 535-548.

Sargent, T.J. 1999 The Conquest of American Inflation. Princeton: Princeton University Press.

Shiller, R.J., 1981. Do stock prices move too much to be justified by subsequent changes in dividends? American Economic Review 71, 421-436.

Shiller, R.J. 2005 Irrational exhuberence, 2nd Edition. Princeton NJ: Princeton University Press. Updated data from http://www.econ.yale.edu/ ${ }^{\sim}$ shiller/data.htm

Suh, H. 2012 Macroprudential policy: Its effects and relationship to monetary policy, Federal Reserve Bank of Philadelphia, Working Paper 12-28.

Tal, B. 2006 How painful will mortgage resets be? CIBC World Markets Inc., Consumer Watch U.S. (October 18).

Taylor, J.B. 1999. A historical analysis of monetary policy rules," in J.B. Taylor, (ed.), Monetary Policy Rules Chicago: University of Chicago Press, pp. 319-341.

U.S. Financial Crisis Inquiry Commission 2011 Final report on the causes of the financial and economic crisis in the United States, Pursuant to Public Law 111-2 (January).

Walentin, K. and P. Sellin 2010 Housing collateral and the monetary transmission mechanism, Sverges Riksbank Working Paper 239.

Wolff, E.N. 2006 Changes in household wealth in the 1980s and 1990s in the U.S., in E.N. Wolff (ed.), International Perspectives on Household Wealth. Northampton MA: Edward Elgar Publishing Inc., pp. 107-150.

Woodford, M. 2012 Inflation targeting and financial stability, NBER Working Paper 17967.

Yellen, J. 2009. A Minsky meltdown: Lessons for central bankers. Presentation for the Levy Institute's 18th annual Hyman P. Minsky Conference (April 16). 
Table 1. Model Calibration

\begin{tabular}{lcc}
\hline \hline Parameter & Symbol & Value \\
Exponent on capital in production function & $\alpha$ & 0.342 \\
Capital depreciation rate & $\delta$ & 0.025 \\
Investment adjustment cost & $\psi$ & 5 \\
Discount factor of patient households & $\beta_{1}$ & 0.98 \\
Discount factor of impatient households & $\beta_{2}$ & 0.95 \\
Habit formation parameter & $b$ & 0.7 \\
Labor supply elasticity parameter & $\varphi_{L}$ & 0.1 \\
Disutility of labor, patient households & $\nu_{1, L}$ & 1.19 \\
Disutility of labor, impatient households & $\nu_{2, L}$ & 4.54 \\
Utility from housing services, patient households & $\nu_{1, h}$ & 0.40 \\
Utility from housing services, impatient households & $\nu_{2, h}$ & 0.10 \\
Steady state loan-to-value ratio & $\gamma$ & 0.7 \\
Calvo price adjustment parameter & $\theta_{\pi}$ & 0.75 \\
Price indexation parameter & $\iota_{\pi}$ & 0.25 \\
Elasticity of substitution for intermediate goods & $\theta$ & 33.33 \\
Technology shock innovation, standard deviation & $\sigma_{z}$ & 0.0125 \\
Cost-push shock innovation, standard deviation & $\sigma_{u}$ & 0.0050 \\
Monetary policy shock innovation, standard deviation & $\sigma_{\varsigma}$ & 0.0030 \\
Technology shock persistence & $\rho_{z}$ & 0.9 \\
Cost-push shock persistence & $\rho_{u}$ & 0 \\
Monetary policy shock persistence & $\rho_{\varsigma}$ & 0.8 \\
Interest rate response to inflation & $\alpha_{\pi}$ & 1.5 \\
Interest rate response to output & $\alpha_{y}$ & 0.25 \\
Interest rate response to house price growth & $\alpha_{q}$ & 0 or 0.2 \\
Interest rate response to credit growth & $\alpha_{b}$ & 0 or 0.2 \\
Fraction of agents with moving-average forecast rule & $\omega$ & 0.30 \\
Weight on recent data in moving-average forecast rule & $\lambda$ & 0.35 \\
Weight on wage income in borrowing constraint & $m$ & 0 or 0.75 \\
Level parameter in generalized borrowing constraint & $\widehat{\gamma}$ & 1.153 \\
\hline \hline
\end{tabular}


Table 2. Volatility Comparison: Data vs. Models

\begin{tabular}{lccc}
\hline \hline & \multicolumn{2}{c}{ Standard deviations } \\
\hline & $\begin{array}{c}\text { House } \\
\text { Price }\end{array}$ & $\begin{array}{c}\text { Household } \\
\text { Debt }\end{array}$ & Output \\
\hline $\begin{array}{l}\text { Rational } \\
\text { Expectations }\end{array}$ & 3.14 & 6.15 & 2.51 \\
$\begin{array}{l}\text { Hybrid } \\
\text { Expectations }\end{array}$ & 4.60 & 9.97 & 3.51 \\
$\begin{array}{l}\text { U.S. Data } \\
\text { 1987.Q3 to 2012.Q1 }\end{array}$ & 6.30 & 9.37 & 3.54 \\
\hline \hline
\end{tabular}

Notes: U.S. data statistics are computed from the detrended data plotted in Figure 1. Model statistics are computed from simulated series and expressed as percent deviations from steady state 
Table 3. Volatility Comparison: Rational vs. Hybrid Expectations

\begin{tabular}{lcccccccc}
\hline \hline & \multicolumn{7}{c}{ Standard deviations } \\
& $\begin{array}{c}\text { House } \\
\text { Price }\end{array}$ & $\begin{array}{c}\text { Household } \\
\text { Debt }\end{array}$ & $\begin{array}{c}\text { Price of } \\
\text { Capital }\end{array}$ & Consum. & Output & $\begin{array}{c}\text { Labor } \\
\text { Hours }\end{array}$ & $\begin{array}{c}\text { Policy } \\
\text { Rate }\end{array}$ & Infl. \\
\hline $\begin{array}{l}\text { Rational } \\
\text { Expectations }\end{array}$ & 3.14 & 6.14 & 1.66 & 2.05 & 2.51 & 1.88 & 2.09 & 1.64 \\
$\begin{array}{l}\text { Hybrid } \\
\text { Expectations }\end{array}$ & 4.60 & 9.97 & 2.23 & 2.56 & 3.51 & 2.54 & 2.40 & 2.00 \\
$\begin{array}{l}\text { Volatility } \\
\text { Ratio }\end{array}$ & 1.47 & 1.62 & 1.35 & 1.25 & 1.40 & 1.35 & 1.15 & 1.22 \\
\hline \hline
\end{tabular}

Note: Standard deviations are computed from simulated series and expressed as percent deviation from steady state.

Table 4. Persistence Comparison: Rational vs. Hybrid Expectations

\begin{tabular}{lcccccccc}
\hline \hline & \multicolumn{7}{c}{ Autocorrelation coefficient } \\
\hline & $\begin{array}{c}\text { House } \\
\text { price }\end{array}$ & $\begin{array}{c}\text { Household } \\
\text { Debt }\end{array}$ & $\begin{array}{c}\text { Price of } \\
\text { Capital }\end{array}$ & Consum. & Output & $\begin{array}{c}\text { Labor } \\
\text { Hours }\end{array}$ & $\begin{array}{c}\text { Policy } \\
\text { rate }\end{array}$ & Infl. \\
\hline $\begin{array}{l}\text { Rational } \\
\text { Expectations }\end{array}$ & 0.82 & 0.68 & 0.48 & 0.66 & 0.98 & 0.63 & 0.98 & 0.94 \\
$\begin{array}{l}\text { Hybrid } \\
\text { Expectations }\end{array}$ & 0.91 & 0.83 & 0.63 & 0.75 & 0.99 & 0.67 & 0.99 & 0.95 \\
$\begin{array}{l}\text { Persistence } \\
\text { Ratio }\end{array}$ & 1.11 & 1.22 & 1.31 & 1.13 & 1.01 & 1.07 & 1.01 & 1.02 \\
\hline \hline
\end{tabular}

Note: Autocorrelation coefficients are computed using simulated series. 
Table 5. Monetary Policy Experiments

\begin{tabular}{|c|c|c|c|c|c|c|c|c|}
\hline & \multicolumn{8}{|c|}{ Standard deviations } \\
\hline & $\begin{array}{l}\text { House } \\
\text { Price }\end{array}$ & $\begin{array}{l}\text { Household } \\
\text { Debt }\end{array}$ & $\begin{array}{l}\text { Price of } \\
\text { Capital }\end{array}$ & Consum. & Output & $\begin{array}{l}\text { Labor } \\
\text { Hours }\end{array}$ & $\begin{array}{c}\text { Policy } \\
\text { Rate }\end{array}$ & Infl. \\
\hline & \multicolumn{8}{|c|}{ Interest rate response to house price growth } \\
\hline \multicolumn{9}{|l|}{ Rational } \\
\hline$\alpha_{q}=0$ & 3.14 & 6.15 & 1.66 & 2.05 & 2.51 & 1.88 & 2.09 & 1.64 \\
\hline$\alpha_{q}=0.2$ & 3.18 & 5.81 & 1.57 & 2.01 & 2.55 & 2.15 & 1.94 & 1.72 \\
\hline Volatility Ratio & 1.01 & 0.95 & 0.94 & 0.98 & 1.02 & 1.15 & 0.93 & 1.05 \\
\hline \multicolumn{9}{|l|}{ Hybrid } \\
\hline$\overline{\alpha_{q}}=0$ & 4.60 & 9.97 & 2.23 & 2.56 & 3.51 & 2.54 & 2.40 & 2.00 \\
\hline$\alpha_{q}=0.2$ & 5.04 & 9.51 & 2.51 & 2.62 & 3.61 & 2.86 & 2.63 & 2.34 \\
\hline Volatility Ratio & 1.10 & 0.95 & 1.13 & 1.02 & 1.03 & 1.13 & 1.09 & 1.18 \\
\hline & \multicolumn{8}{|c|}{ Interest rate response to credit growth } \\
\hline$\underline{\text { Rational }}$ & & & & & & & & \\
\hline$\alpha_{b}=0$ & 3.14 & 6.15 & 1.66 & 2.05 & 2.51 & 1.88 & 2.09 & 1.64 \\
\hline$\alpha_{b}=0.2$ & 3.12 & 3.31 & 1.50 & 2.04 & 2.56 & 1.95 & 1.97 & 1.66 \\
\hline Volatility Ratio & 0.99 & 0.54 & 0.90 & 0.99 & 1.02 & 1.04 & 0.94 & 1.01 \\
\hline \multicolumn{9}{|l|}{ Hybrid } \\
\hline$\overline{\alpha_{b}}=0$ & 4.60 & 9.97 & 2.23 & 2.56 & 3.51 & 2.54 & 2.40 & 2.00 \\
\hline$\alpha_{b}=0.2$ & 5.03 & 10.75 & 2.45 & 2.71 & 3.56 & 2.75 & 3.35 & 3.24 \\
\hline Volatility Ratio & 1.09 & 1.08 & 1.10 & 1.06 & 1.01 & 1.08 & 1.39 & 1.63 \\
\hline
\end{tabular}

Note: Standard deviations are computed from simulated series and expressed as percent deviations from steady state. 
Table 6. Macroprudential Policy Experiments

\begin{tabular}{|c|c|c|c|c|c|c|c|c|}
\hline & \multicolumn{8}{|c|}{ Standard deviations } \\
\hline & $\begin{array}{l}\text { House } \\
\text { Price }\end{array}$ & $\begin{array}{l}\text { Household } \\
\text { Debt }\end{array}$ & $\begin{array}{l}\text { Price of } \\
\text { Capital }\end{array}$ & Consum. & Output & $\begin{array}{l}\text { Labor } \\
\text { Hours }\end{array}$ & $\begin{array}{c}\text { Policy } \\
\text { Rate }\end{array}$ & Infl. \\
\hline & \multicolumn{8}{|c|}{ Reduced loan-to-value ratio } \\
\hline \multicolumn{9}{|l|}{ Rational } \\
\hline$\gamma=0.7$ & 3.14 & 6.15 & 1.66 & 2.05 & 2.51 & 1.88 & 2.09 & 1.64 \\
\hline$\gamma=0.5$ & 3.25 & 4.50 & 1.75 & 2.04 & 2.53 & 1.88 & 2.17 & 1.64 \\
\hline Volatility Ratio & 1.04 & 0.73 & 1.06 & 0.99 & 1.01 & 1.00 & 1.04 & 1.00 \\
\hline \multicolumn{9}{|l|}{ Hybrid } \\
\hline$\gamma=0.7$ & 4.60 & 9.97 & 2.23 & 2.56 & 3.51 & 2.54 & 2.40 & 2.00 \\
\hline$\gamma=0.5$ & 4.49 & 8.16 & 2.23 & 2.56 & 3.58 & 2.58 & 2.41 & 1.97 \\
\hline Volatility Ratio & 0.98 & 0.82 & 1.00 & 1.00 & 1.02 & 1.02 & 1.00 & 0.99 \\
\hline & \multicolumn{8}{|c|}{ Generalized borrowing constraint } \\
\hline \multicolumn{9}{|l|}{$\underline{\text { Rational }}$} \\
\hline$m=0$ & 3.14 & 6.15 & 1.66 & 2.05 & 2.51 & 1.88 & 2.09 & 1.66 \\
\hline$m=0.75$ & 3.21 & 4.06 & 1.71 & 2.04 & 2.53 & 1.90 & 2.14 & 1.63 \\
\hline Volatility Ratio & 1.03 & 0.66 & 1.03 & 1.00 & 1.01 & 1.01 & 1.02 & 0.99 \\
\hline \multicolumn{9}{|l|}{ Hybrid } \\
\hline$\overline{m=0}$ & 4.60 & 9.97 & 2.23 & 2.56 & 3.51 & 2.54 & 2.40 & 2.00 \\
\hline$m=0.75$ & 4.38 & 5.10 & 2.18 & 2.55 & 3.52 & 2.48 & 2.41 & 1.94 \\
\hline Volatility Ratio & 0.95 & 0.51 & 0.98 & 1.00 & 1.00 & 0.98 & 1.00 & 0.97 \\
\hline
\end{tabular}

Note: Standard deviations are computed from simulated series and expressed as percent deviations from steady state. 
U.S. real house prices (in logs)

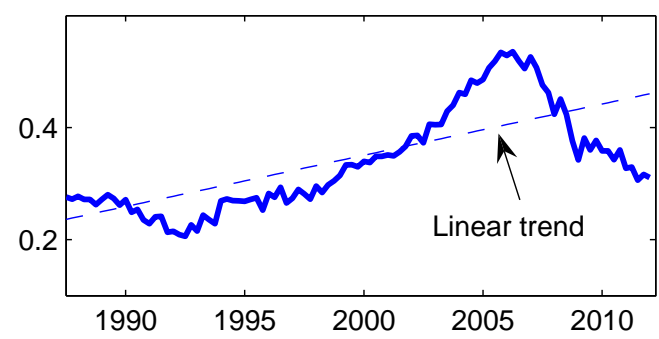

U.S. real household debt per capita (in logs)

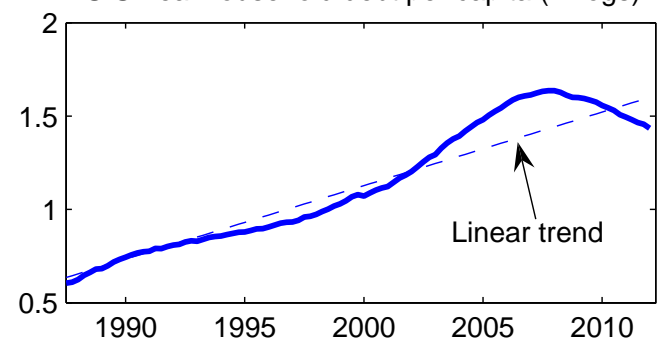

U.S. real GDP per capita (in logs)

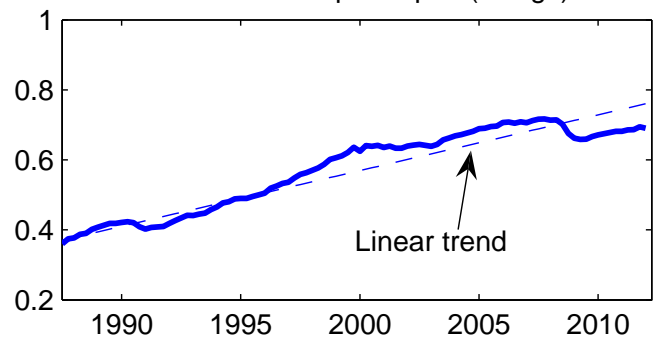

U.S. real house prices

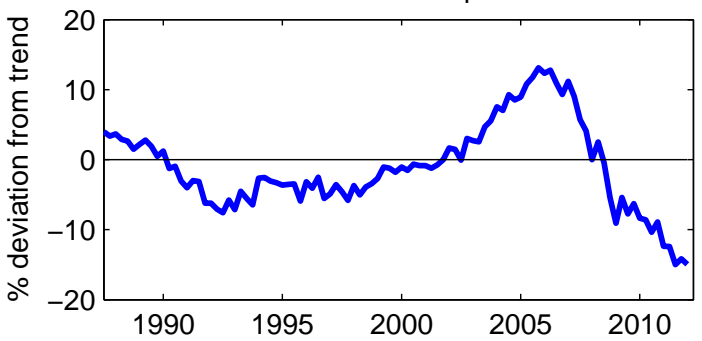

U.S. real household debt per capita

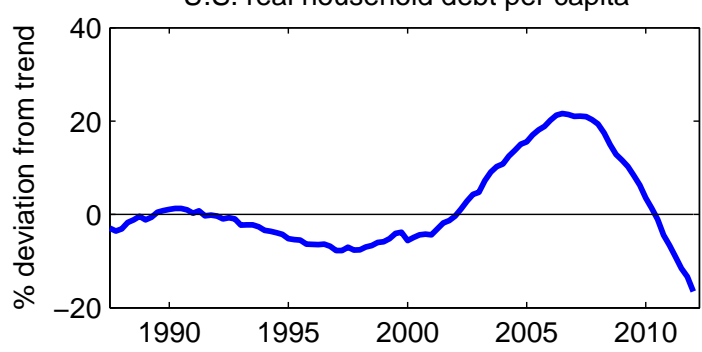

U.S. real GDP per capita

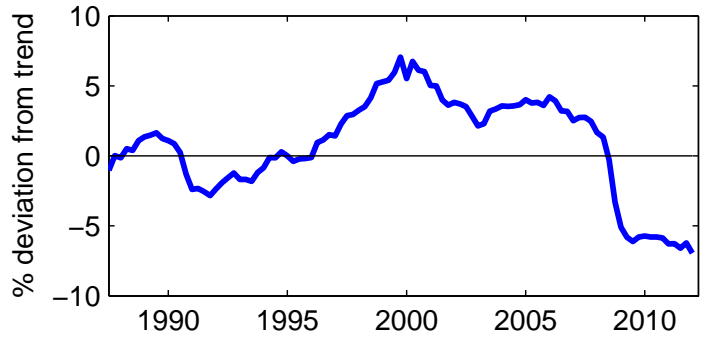

Figure 1: U.S. real house prices (from U.S. Census Bureau) and real household debt (from Federal Reserve Flow of Funds) both increased dramatically starting around the year 2000. During the boom years, per capita real GDP remained consistently above trend. House prices have since retraced to the downside while the level of household debt has declined slightly. Real GDP experienced a sharp drop during the Great Recession and remains about 5\% below trend. 


\section{Case Shiller Index and Futures}

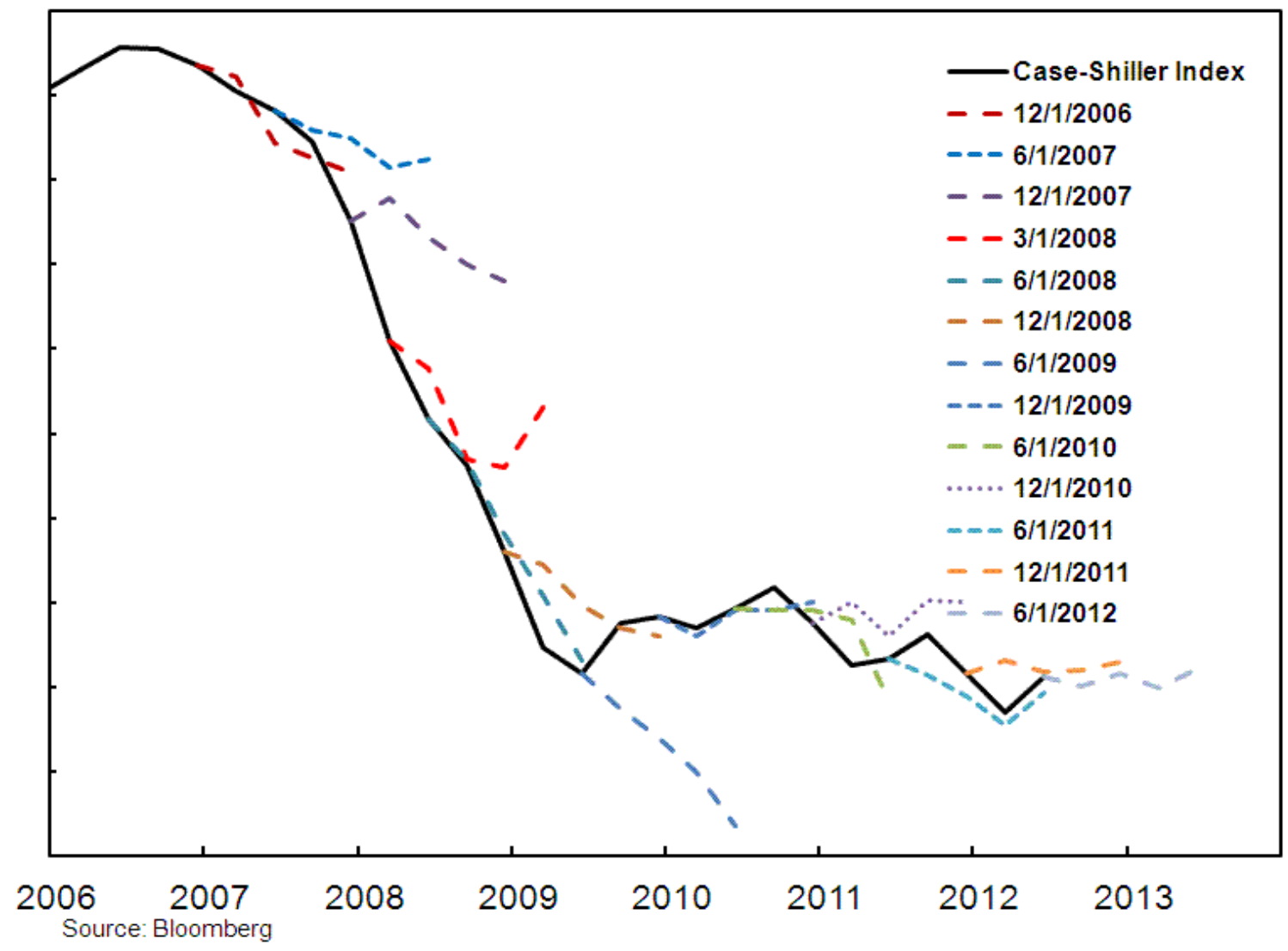

Figure 2: Futures market forecasts for house prices tend to overpredict subsequent actual house prices when prices are falling - a pattern consistent with a moving-average forecast rule. 
U.S. Survey Expected Inflation versus Subsequent Actual Inflation

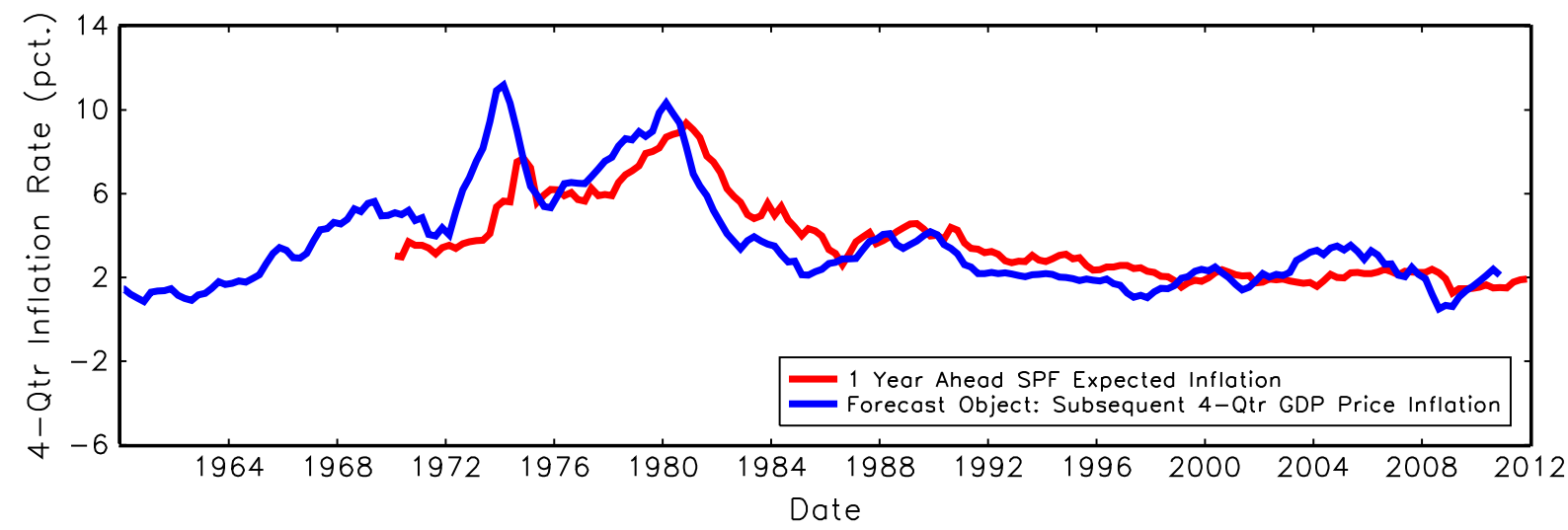

U.S. Survey Expected Inflation versus Moving Average of Past Inflation

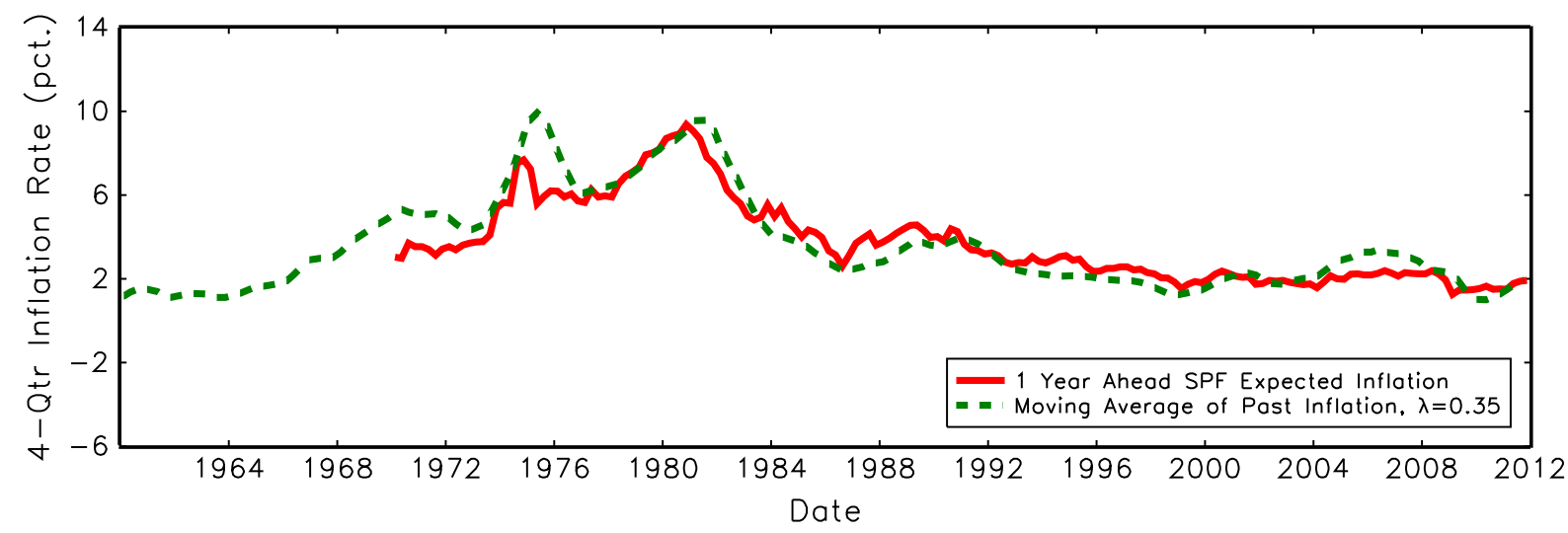

Figure 3: U.S. inflation expectations derived from the Survey of Professional Forecasters (SPF) tend to systematically underpredict subsequent actual inflation in the sample period prior to 1979 when inflation was rising and systematically overpredict it thereafter when inflation was falling. The survey pattern is well-captured by a moving-average of past inflation rates. 


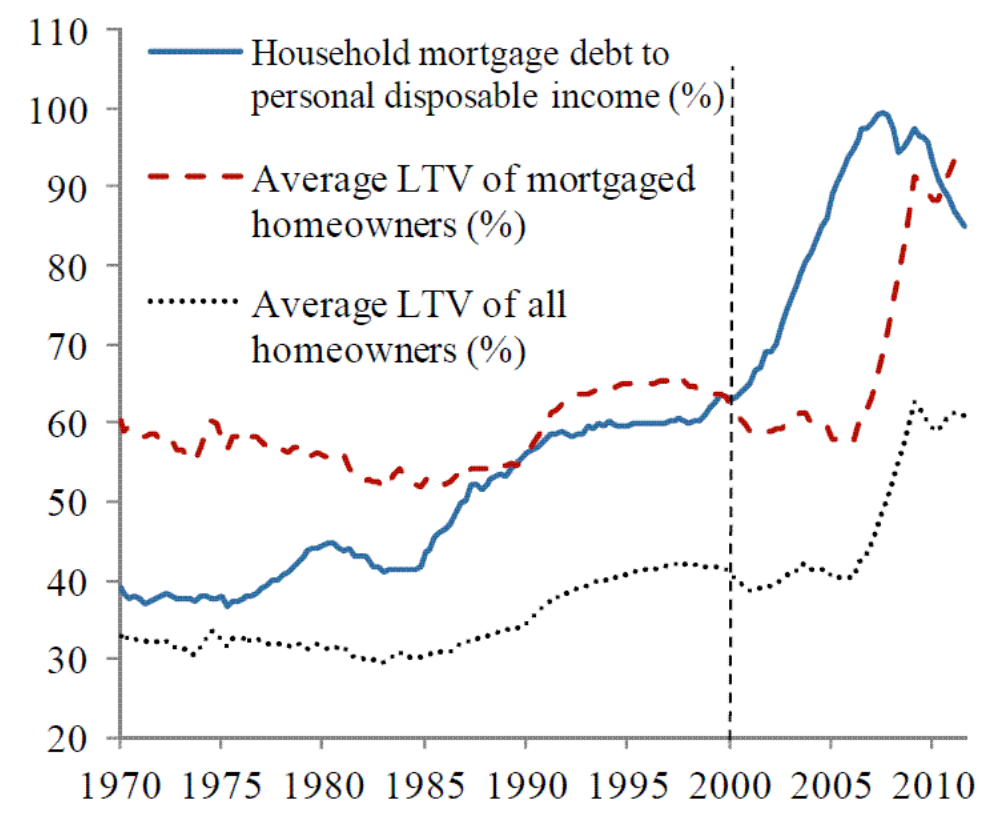

Figure 4: During the U.S. housing boom of the mid-2000s, loan-to-value measures did not signal a significant increase in household leverage because the value of housing assets rose together with household debt in a self-reinforcing feedback loop. In contrast, the debt-toincome ratio provided regulators with a much earlier warning signal of the dangerous buildup of household leverage. 

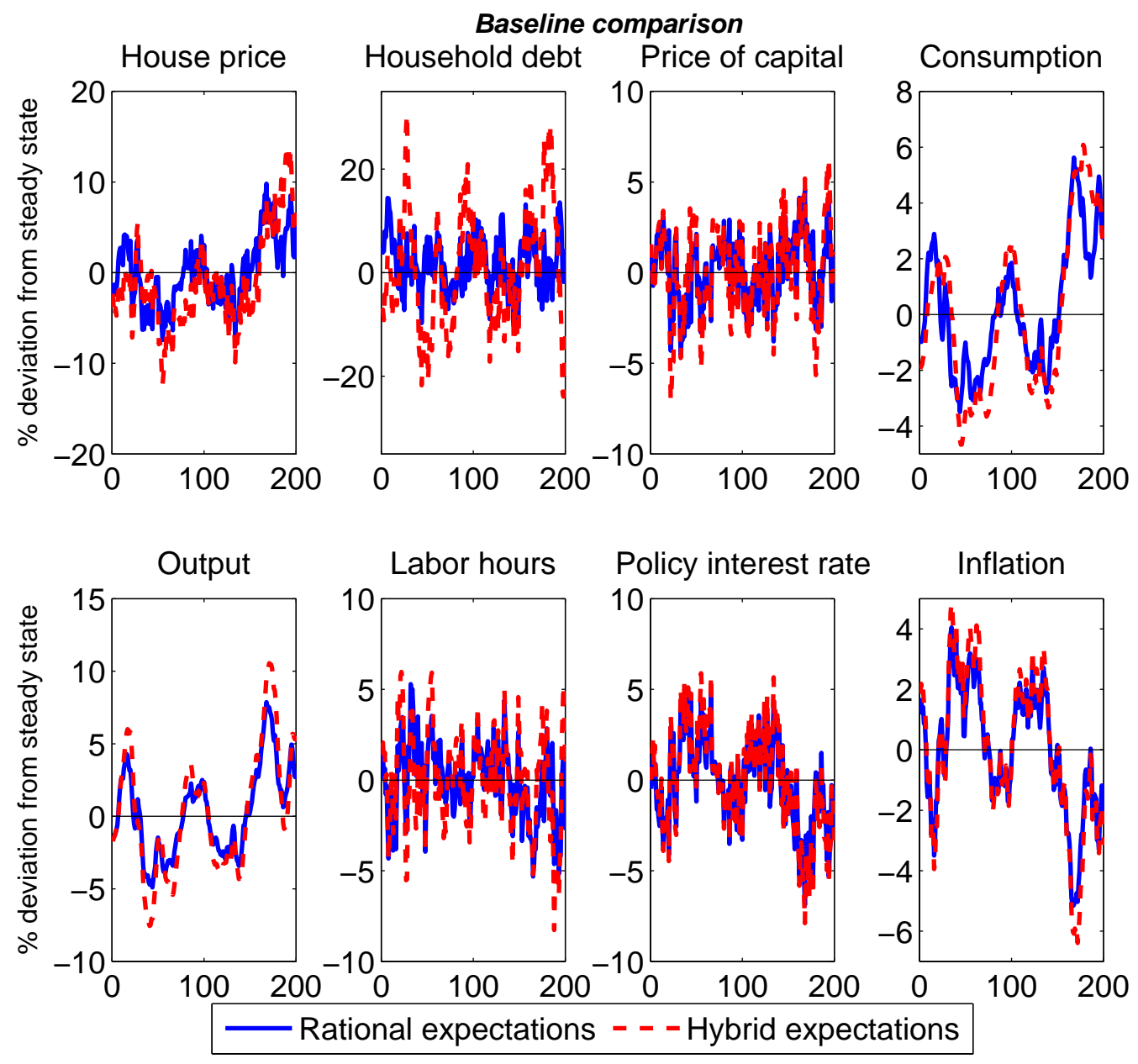

Figure 5: The volatilities of house prices and household debt in the hybrid expectations model are about 1.5 times larger than those in the rational expectations model. The price of capital volatility is magnified by a factor of about 1.4. The volatilities of output, consumption, inflation, and labor hours are magnified by factors ranging from 1.2 to 1.4 . 


\section{Technology shock}
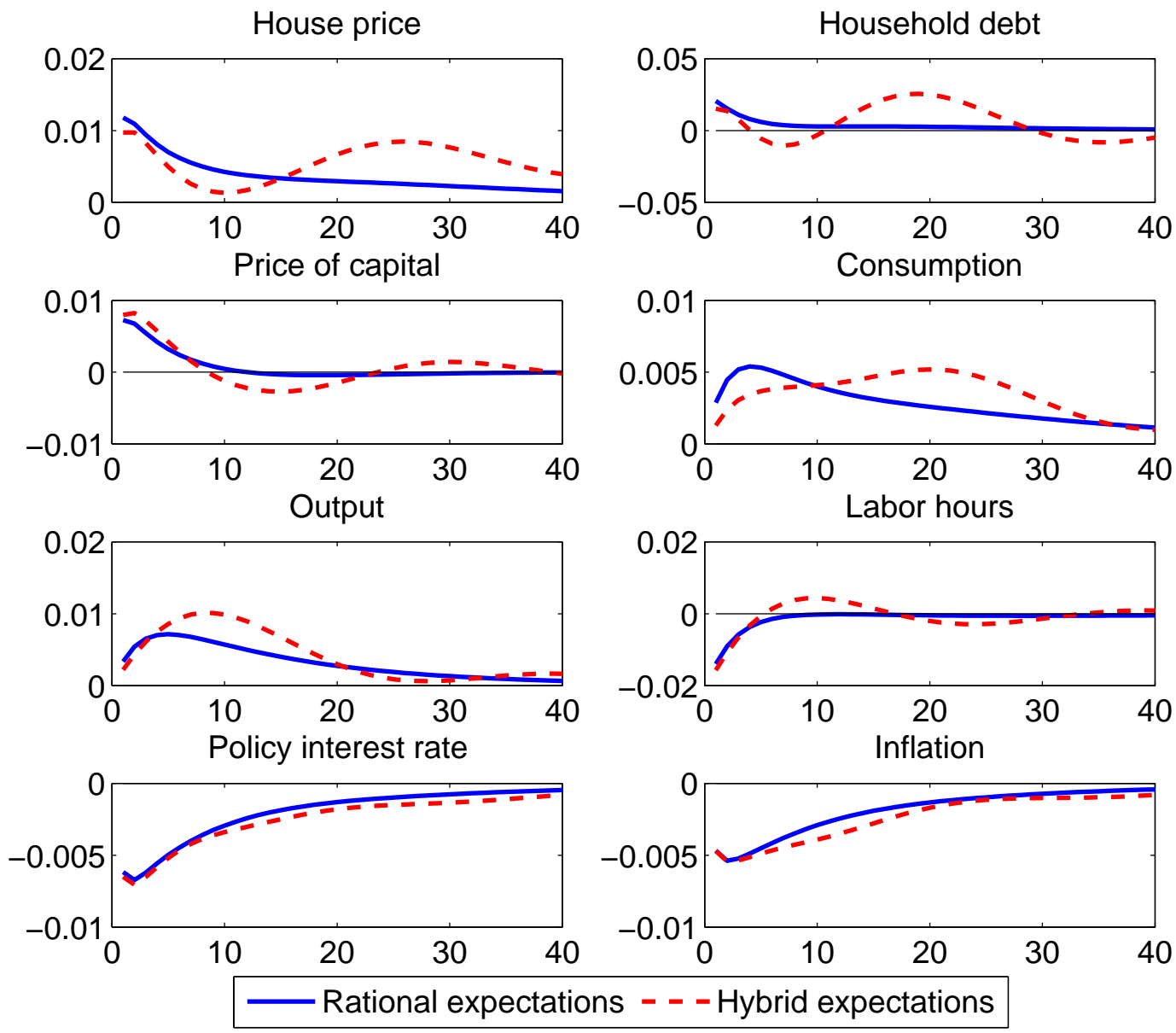

Figure 6: One-standard deviation shock to aggregate productivity. Fluctuations in the hybrid expectations model tend to be more pronounced and longer lasting. 

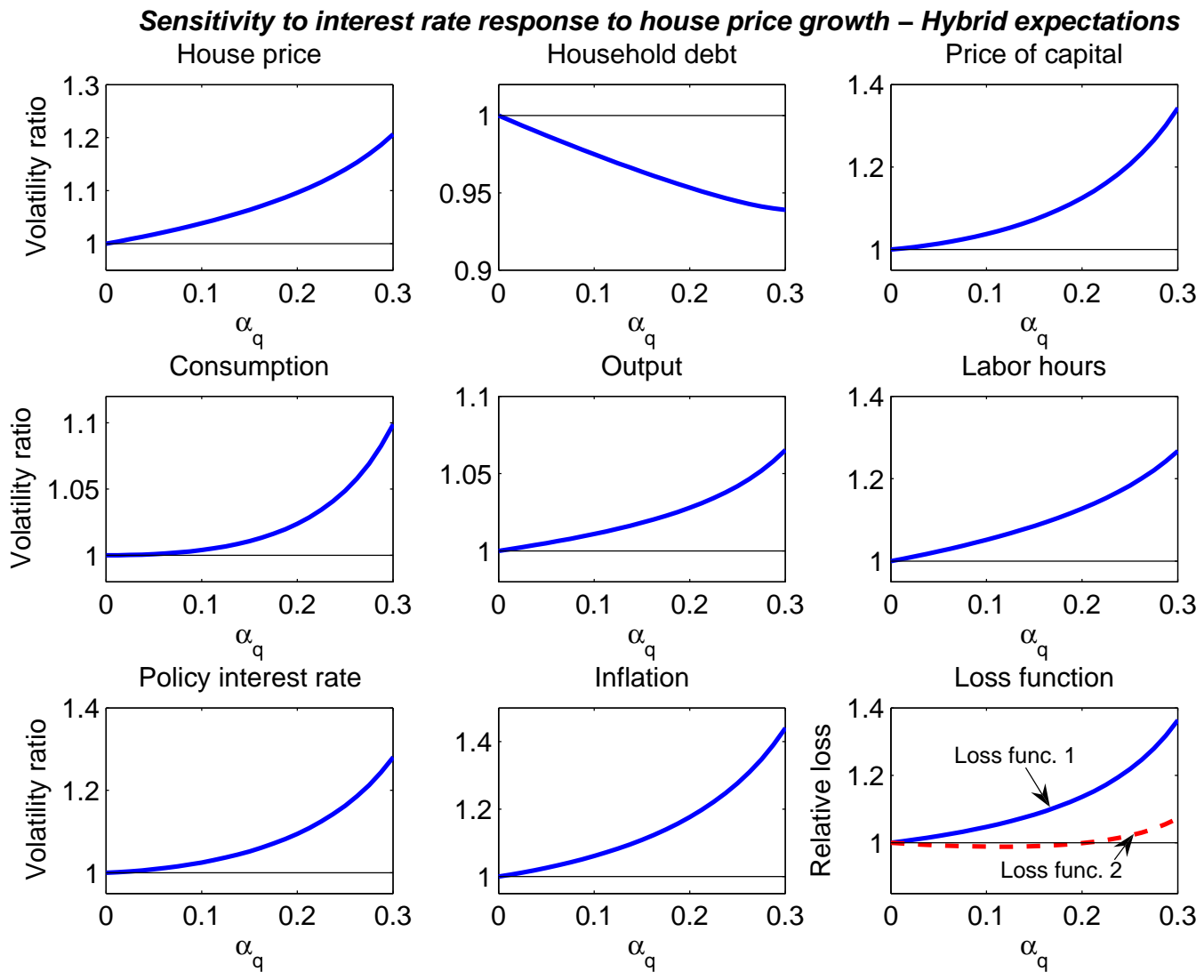

Figure 7: A stronger interest-rate response to house price growth helps to stabilize household debt but it magnifies the volatility of other variables, particularly inflation. The figure plots ratios relative to the hybrid expectations model with $\alpha_{q}=0$. Loss function $1=\operatorname{Var}\left(\pi_{t}\right)+$ $\operatorname{Var}\left(y_{t}\right)$. Loss function $2=\operatorname{Var}\left(\pi_{t}\right)+\operatorname{Var}\left(y_{t}\right)+0.25 \operatorname{Var}\left(b_{2, t}\right)$. 


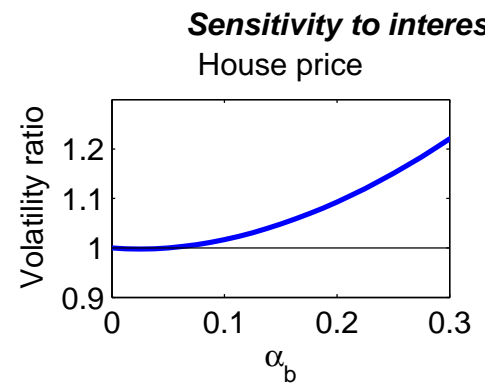

Sensitivity to interest rate response to credit growth - Hybrid expectations

Consumption

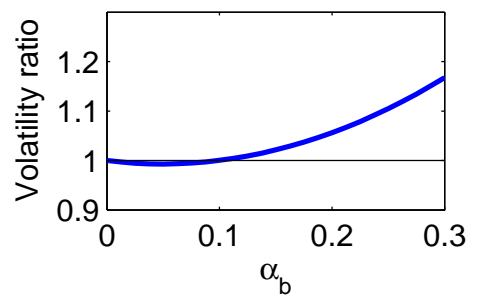

Policy interest rate

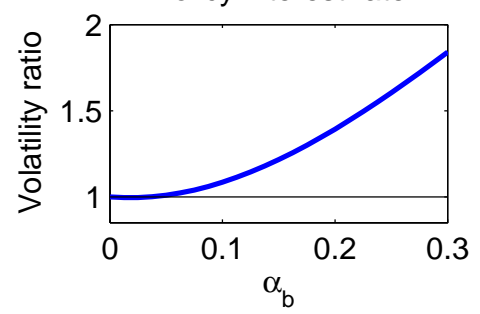

Household debt

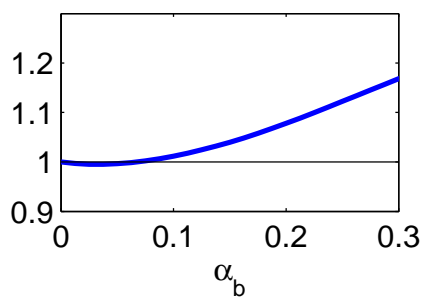

Output

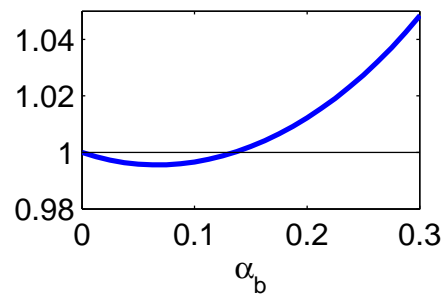

Inflation

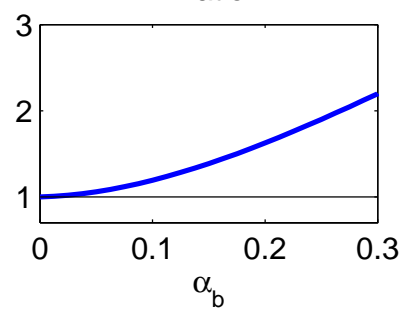

Price of capital

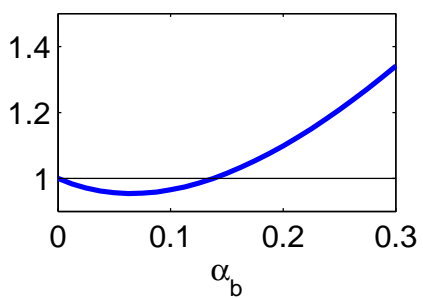

Labor hours

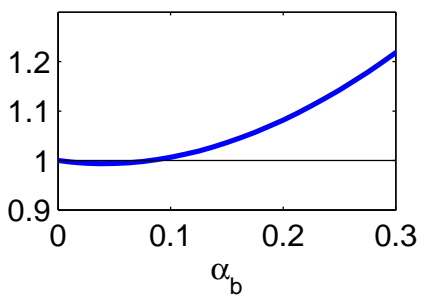

Loss function

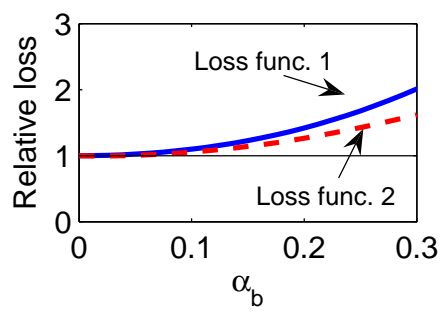

Figure 8: A stronger interest-rate response to credit growth magnifies the volatility of most variables, particularly inflation. The figure plots ratios relative to the hybrid expectations model with $\alpha_{b}=0$. Loss function $1=\operatorname{Var}\left(\pi_{t}\right)+\operatorname{Var}\left(y_{t}\right)$. Loss function $2=\operatorname{Var}\left(\pi_{t}\right)+$ $\operatorname{Var}\left(y_{t}\right)+0.25 \operatorname{Var}\left(b_{2, t}\right)$. 


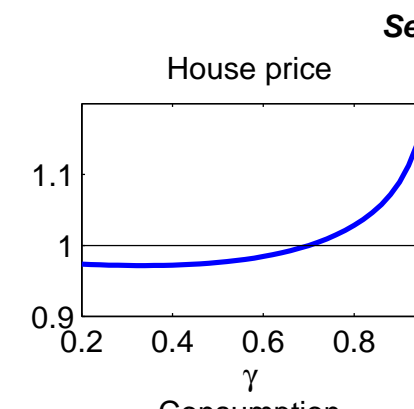

Sensitivity to LTV ratio - Hybrid expectations
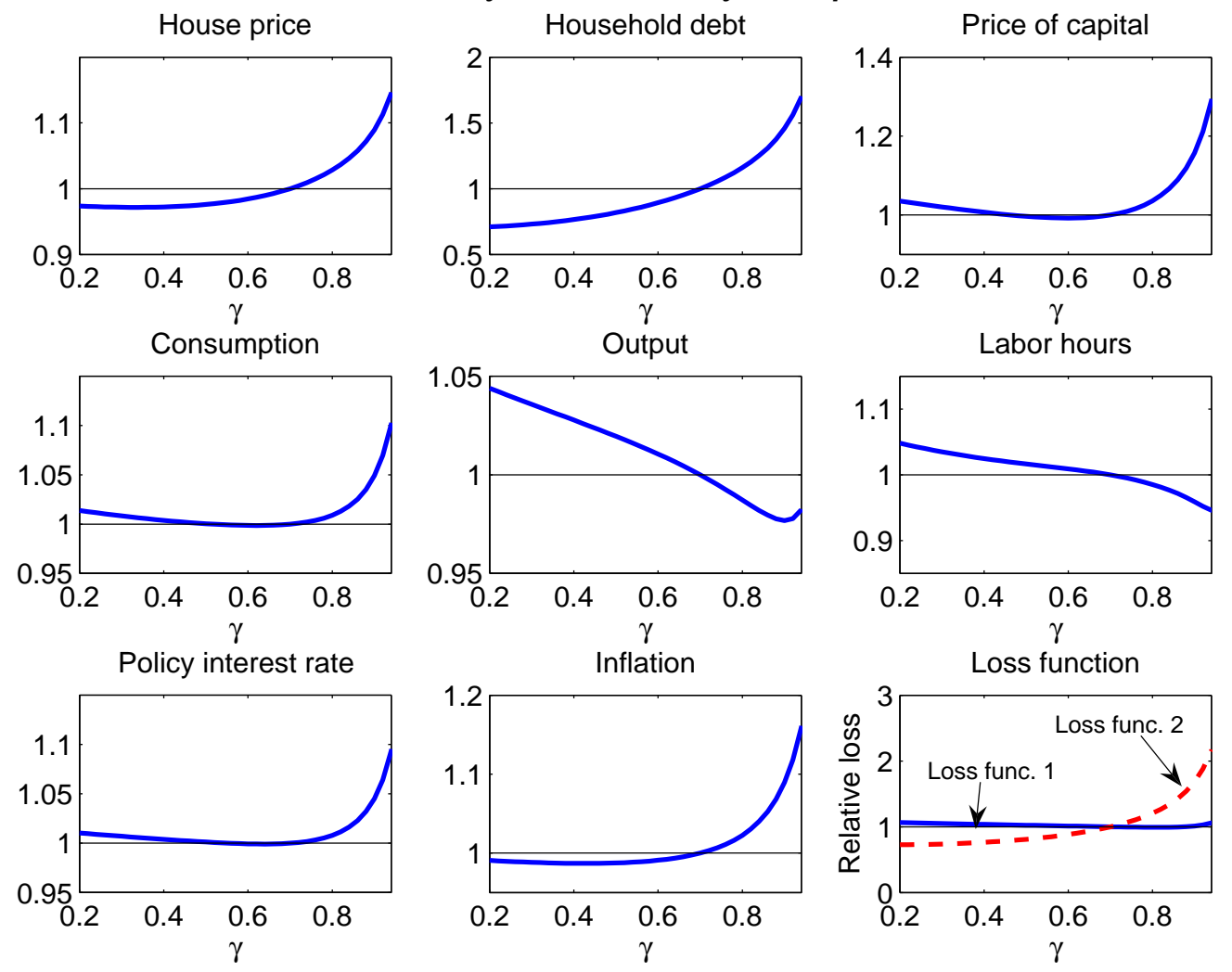

Figure 9: A tightening of lending standards in the form of a reduction in the loan-to-value ratio $\gamma$ helps to stabilize house prices and household debt but it magnifies the volatility of output and labor hours. The figure plots ratios relative to the baseline hybrid expectations model with $\gamma=0.7$. Loss function $1=\operatorname{Var}\left(\pi_{t}\right)+\operatorname{Var}\left(y_{t}\right)$. Loss function $2=\operatorname{Var}\left(\pi_{t}\right)+$ $\operatorname{Var}\left(y_{t}\right)+0.25 \operatorname{Var}\left(b_{2, t}\right)$. 


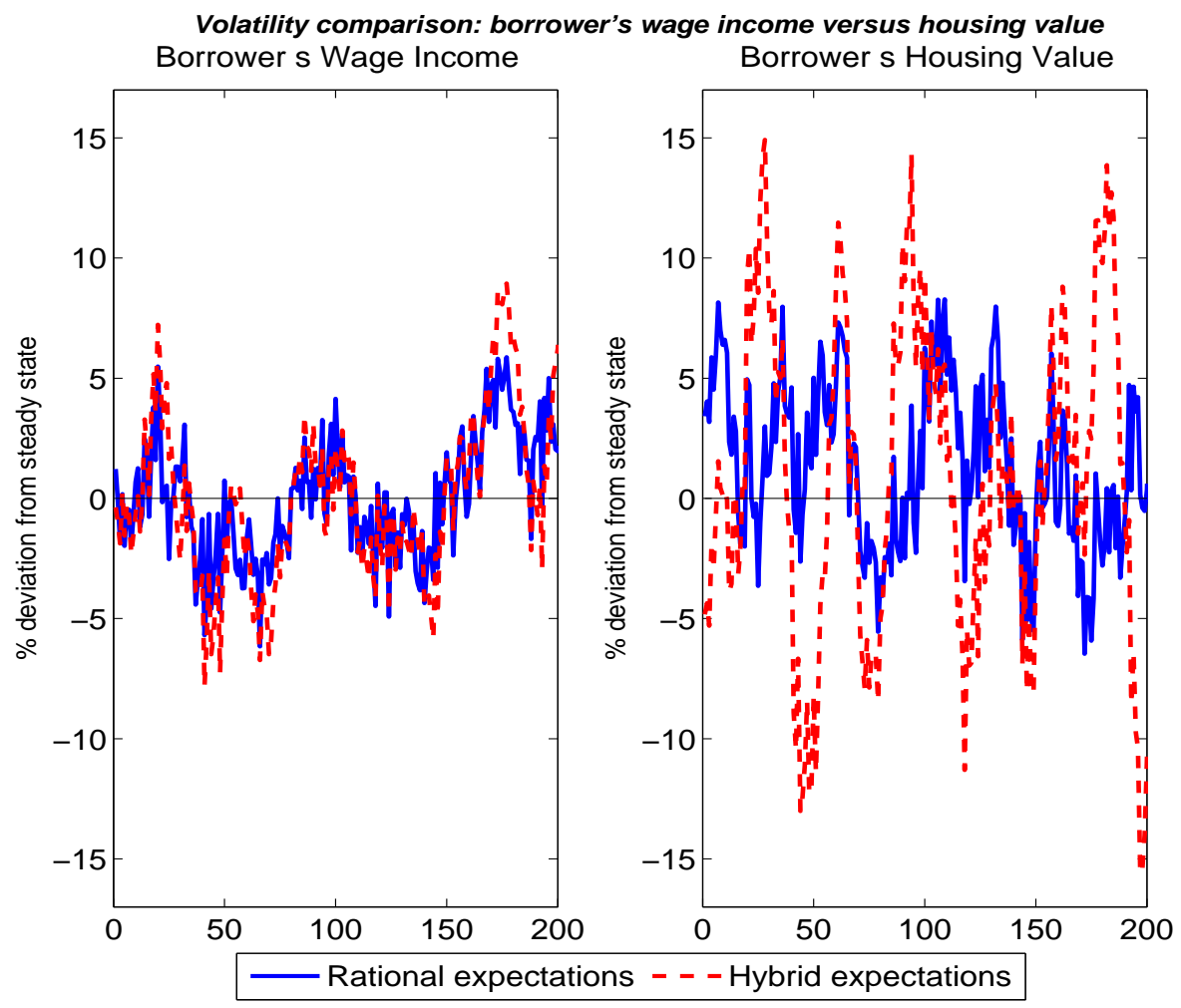

Figure 10: When expectations are fully-rational, the volatilties of the borrower's wage income and housing value are roughly similar, so it does not make much difference which one is included in the collateral constraint. However, when expectations are not fully-rational, the volatility of the borrower's housing value greatly exceeds the volatility of the borrower's wage income. In this case, excess volatility in housing value is transmitted directly to excess volatility in household debt, which is harmful from a financial stability perspective. 

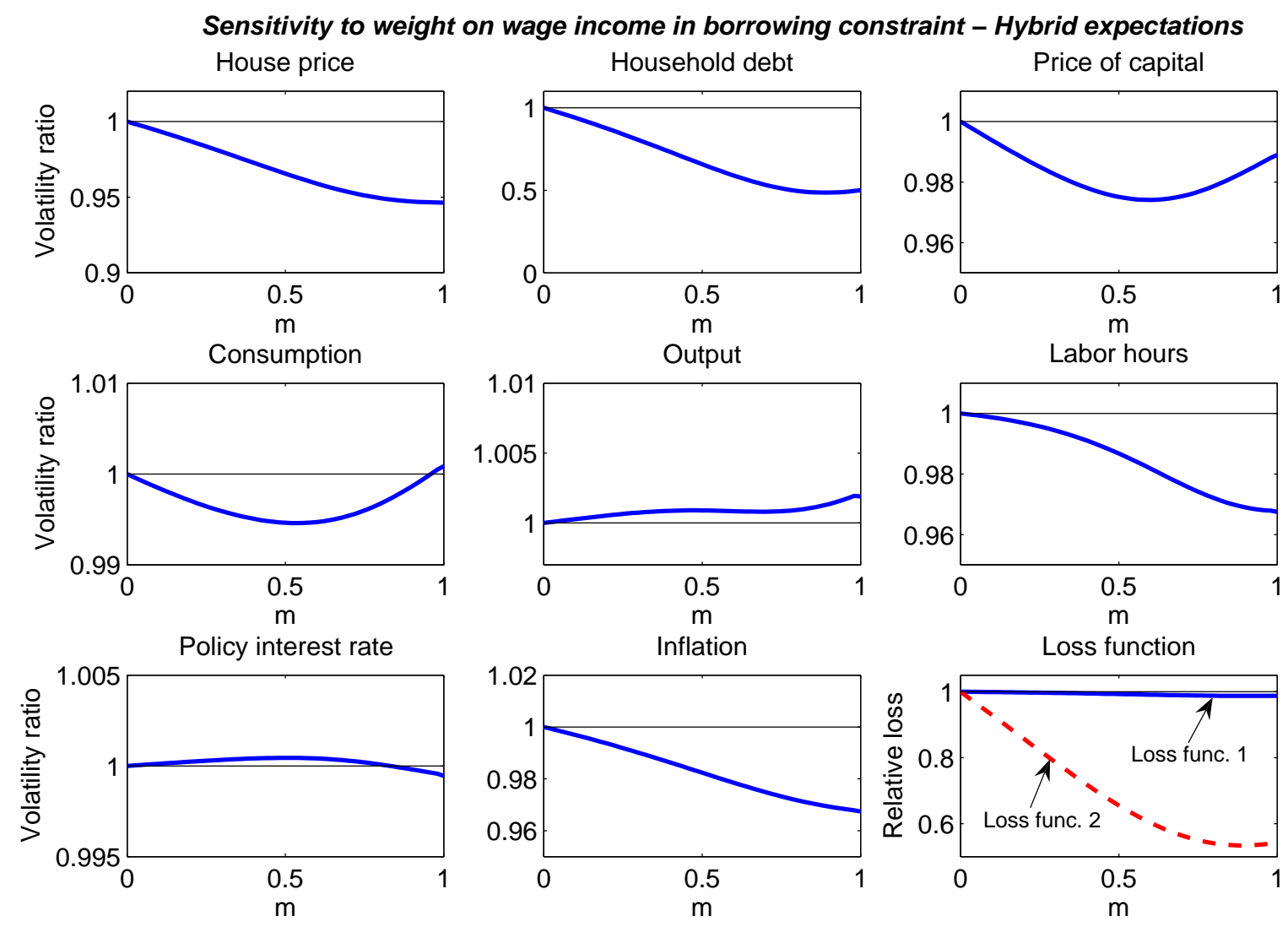

Figure 11: Increasing the weight on the borrower's wage income in the borrowing constraint helps to stabilize house prices and household debt while reducing the volatilities of labor hours and inflation. Output volatility is little changed. The figure plots ratios relative to the hybrid expectations model with $m=0$. Loss function $1=\operatorname{Var}\left(\pi_{t}\right)+\operatorname{Var}\left(y_{t}\right)$. Loss function $2=\operatorname{Var}\left(\pi_{t}\right)+\operatorname{Var}\left(y_{t}\right)+0.25 \operatorname{Var}\left(b_{2, t}\right)$. 


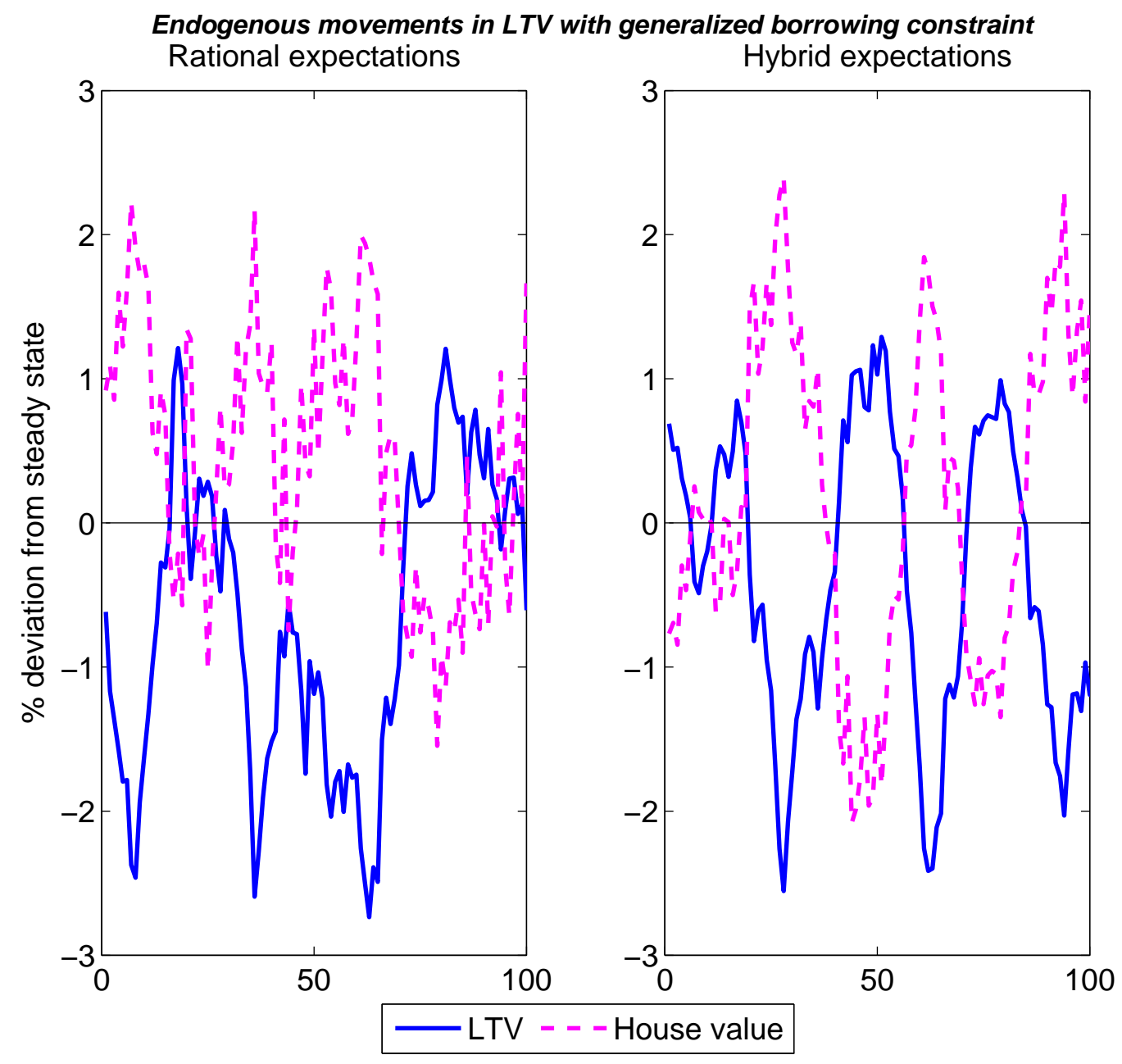

Figure 12: Model simulations using the generalized borrowing constraint (20) which places a substantial weight $(m=0.75)$ on the borrower's wage income. The observed loan-to-value ratio exhibits endogenous countercyclicality which serves as an automatic stabilizer. 